\title{
, \\ Highly Stable, Cold-Active Aldehyde Dehydrogenase from the Marine Antarctic Flavobacterium sp. PL002
}

\author{
Georgiana Necula-Petrareanu ${ }^{1}$, Paris Lavin ${ }^{2}$, Victoria Ioana Paun ${ }^{1}$, Giulia Roxana Gheorghita ${ }^{1}$, \\ Alina Vasilescu ${ }^{3}$ (I) and Cristina Purcarea ${ }^{1, *}$ \\ 1 Department of Microbiology, Institute of Biology, 296 Splaiul Independentei, 060031 Bucharest, Romania; \\ georgiana.petrareanu@ibiol.ro (G.N.-P.); ioana.paun@ibiol.ro (V.I.P.); giulia.gheaorghita@unibuc.ro (G.R.G.) \\ 2 Departamento de Biotecnologia, Facultad de Ciencias del Mar y Recursos Biologicos, \\ Universidad de Antofagasta, 601 Avenida Angamos, Antofagasta 1270300, Chile; paris.lavin@uantof.cl \\ 3 International Centre of Biodynamics, 1B Intrarea Portocalelor, 060101 Bucharest, Romania; \\ avasilescu@biodyn.ro \\ * Correspondence: cristina.purcarea@ibiol.ro
}

Citation: Necula-Petrareanu, G.; Lavin, P.; Paun, V.I.; Gheorghita, G.R.; Vasilescu, A.; Purcarea, C. Highly Stable, Cold-Active Aldehyde Dehydrogenase from the Marine Antarctic Flavobacterium sp. PL002. Fermentation 2022, 8, 7. https:// doi.org/10.3390/fermentation8010007 Academic Editor: Ronnie G. Willaert

Received: 19 November 2021 Accepted: 23 December 2021 Published: 27 December 2021

Publisher's Note: MDPI stays neutral with regard to jurisdictional claims in published maps and institutional affiliations.

Copyright: (C) 2021 by the authors. Licensee MDPI, Basel, Switzerland. This article is an open access article distributed under the terms and conditions of the Creative Commons Attribution (CC BY) license (https:// creativecommons.org/licenses/by/ $4.0 /)$.

\begin{abstract}
Stable aldehyde dehydrogenases (ALDH) from extremophilic microorganisms constitute efficient catalysts in biotechnologies. In search of active ALDHs at low temperatures and of these enzymes from cold-adapted microorganisms, we cloned and characterized a novel recombinant ALDH from the psychrotrophic Flavobacterium PL002 isolated from Antarctic seawater. The recombinant enzyme (F-ALDH) from this cold-adapted strain was obtained by cloning and expressing of the PL002 aldH gene (1506 bp) in Escherichia coli BL21(DE3). Phylogeny and structural analyses showed a high amino acid sequence identity (89\%) with Flavobacterium frigidimaris ALDH and conservation of all active site residues. The purified F-ALDH by affinity chromatography was homotetrameric, preserving $80 \%$ activity at $4{ }^{\circ} \mathrm{C}$ for 18 days. F-ALDH used both $\mathrm{NAD}^{+}$and $\mathrm{NADP}^{+}$and a broad range of aliphatic and aromatic substrates, showing cofactor-dependent compensatory $K_{\mathrm{M}}$ and $k_{\text {cat }}$ values and the highest catalytic efficiency $\left(0.50 \mu \mathrm{M}^{-1} \mathrm{~s}^{-1}\right)$ for isovaleraldehyde. The enzyme was active in the $4-60{ }^{\circ} \mathrm{C}$-temperature interval, with an optimal $\mathrm{pH}$ of 9.5 , and a preference for $\mathrm{NAD}^{+}$-dependent reactions. Arrhenius plots of both $\mathrm{NAD}(\mathrm{P})^{+}$-dependent reactions indicated conformational changes occurring at $30^{\circ} \mathrm{C}$, with four(five)-fold lower activation energy at high temperatures. The high thermal stability and substrate-specific catalytic efficiency of this novel cold-active ALDH favoring aliphatic catalysis provided a promising catalyst for biotechnological and biosensing applications.
\end{abstract}

Keywords: aldehyde dehydrogenase; cold-active enzyme; Flavobacterium; Antarctic bacteria; thermostable catalyst

\section{Introduction}

Extremophilic bacteria are characterized by tolerance or the capability of growing under extreme conditions, such as hypersaline habitats, high pressures, and extreme temperatures. Many extremophiles inhabiting environments characterized by multiple extreme conditions are known as polyextremophiles [1,2]. The capability to overcome such stressing conditions present in extreme environments, is due to special characteristics of their extremophilic enzymes (extremozymes) [3-5].

In recent decades, research has exploited extreme environments looking for producers of a wide array of biotechnologically useful extremozymes that are one of the great interests for industrial processes, mainly in biocatalysis due to their particular stability and high catalytic activity over a wide range of various parameters (temperature, salinity, $\mathrm{pH}$, etc.) and their coping ability with specific industrial pipeline requirements. Additionally, the use of enzymes in biological processes is considered part of the environmentally friendly chemicals, known as Green Chemistry, which aim to minimize or eliminate the use and production of dangerous substances for human health and environment [6]. The global 
demand for enzymes is expected to grow at an accelerated rate due to their widespread use in food processing, paper, biofuels, pharmaceutical, rubber, textile, photography, biological detergents, leather, and molecular biology sectors. The market for industrial enzymes (e.g., hydrolase, lyase, oxidoreductase, transferase, etc.) is segmented according to the type of catalyzed reaction. Hydrolases represent the most prominent type of enzymes used in the food, beverage, and detergent industries, followed by carbohydrases and proteases. The second largest income generators in the market corresponds to the oxidoreductase enzymes $[7,8]$.

Currently, most of the commercially available enzymes originate from mesophilic microorganisms, which are often sensitive to extreme conditions required by several industrial catalytic processes. Since temperature plays a major role in the catalysts stability and reaction rate, the flexible structures of cold-adapted enzymes compensate the low kinetic energy at lower temperature. This characteristic results in a reduction in activation enthalpy and a more negative activation entropy compared with mesophilic and thermophilic enzymes $[9,10]$. Thus, cold-adapted enzymes can exhibit high catalytic efficiency at low and moderate temperatures as versatile biocatalysts in many industrial applications [11]. Therefore, Antarctic bacteria adapted to low temperatures could be an important source of compounds and enzymes by the mere existence of their novel and diverse metabolic pathways selected by evolutionary pressures present in the Antarctic environments [12-14]. Consequently, for the last decades, Antarctic bioprospecting has been increasing, focusing on identifying new cold adapted enzymes of biotechnological interest [14-16].

Antarctic marine ecosystems constitute a peculiar ecological environment that are characterized by possessing more than one extreme condition, namely temperature, salinity, light climate, and nutrient concentration [17]. Therefore, in this environment the algaassociated heterotrophic bacteria possess immense potential for several biotechnological applications of their extremophilic enzymes [3-5,18]. Many studies on enzymes from bacteria associated with macroalgae are based on agarases, amylases, cellulases, cresolases, hydrogenases, galactosaminidases, galactosidases, glucanases, glycosidases, laccases, lipases, lyases, proteases, pullulanases, quitinases, and xylanases [4,19-23]. However, very little attention had been paid in other cold adapted enzymes like aldehyde dehydrogenase (ALDH, EC 1.2.1.x). This enzyme is responsible for catalyzing the conversion of various aldehydes to carboxylic acids in the presence of $\mathrm{NAD}^{+}$or $\mathrm{NADP}^{+}$as a cofactor, being one of the key enzymes involved in cell detoxification [24]. In addition to their involvement in new metabolic pathways [25,26], ALDHs are important biocatalysts for a series of industrial applications in biotechnologies and biosensing, in the production of 3-hydroxypropionic acid from glycerol [27,28], polyethylene glycol degradation [29], alkanes degradation [30-32], and environmental and wine quality control [33-38]. Currently, limited information is available on the characteristics of cold-active ALDHs. Among these, the enzyme isolated from the psychrotrophic marine Cytophaga sp. (Flavobacterium frigidimaris KUC-1) strain presented an interesting high thermal stability and activity up to $60{ }^{\circ} \mathrm{C}$ [39]. Although aldehyde dehydrogenases are current widely used enzymes for various applications, no cold-active enzyme is available for low temperature catalytic processes.

In this context, we report on the cloning, heterologous expression, and biochemical characterization of a cold-active ALDH from the Antarctic alga-associated Flavobacterium sp. strain PL002, revealing a highly stable recombinant catalyst for oxidizing a broad range of aliphatic and aromatic aldehydes, in contrast with the mesophile-originating homologs. The kinetic properties and a series of functional criteria provided new insight in the applicative potential in biotechnological and biosensing processes of this cold-active ALDH.

\section{Materials and Methods}

\subsection{Cloning and Expression of F-ALDH Coding Gene}

The Flavobacterium PL002 strain isolated from Antarctic seawaters [40] was cultivated for seven days at $15^{\circ} \mathrm{C}$ on Reasoner's 2B broth (R2B, Melford Biolaboratories Ltd., Ipswich, UK) medium [41]. Total DNA was extracted from the collected cells using the 
DNeasy Blood and Tissue kit (Qiagen, Hilden, Germany). The aldH gene (1506 bp) was synthesized (ATG Biosynthetics GmbH, Merzhausen, Germany) and inserted in the pHAT2 expression vector (EMBL, Heidelberg, Germany) using NcoI/BamHI sites. The accuracy of the amplified nucleotide sequence was verified by Sanger sequencing (ATG Biosynthetics $\mathrm{GmbH}$, Merzhausen, Germany). The recombinant plasmid pF-ALDH was used for gene expression in Escherichia coli BL21(DE3) (Thermo Fisher Scientific, Massachusetts, USA). The transformants were cultivated at $37^{\circ} \mathrm{C}$ for $18 \mathrm{~h}$ in Luria broth medium containing $100 \mu \mathrm{g} \mathrm{mL}^{-1}$ ampicillin up to $\mathrm{OD}_{600}=0.750$, and gene expression was performed by induction with $0.5 \mathrm{mM}$ isopropyl- $\beta$-D-thiogalactoside (IPTG) at $25^{\circ} \mathrm{C}$ for $16 \mathrm{~h}$. The induced cells were collected by centrifugation for $10 \mathrm{~min}$ at $9000 \times \mathrm{g}\left(4^{\circ} \mathrm{C}\right)$ and stored at $-80^{\circ} \mathrm{C}$.

\subsection{Purification of Recombinant F-ALDH and Size Exclusion Chromatography}

The recombinant F-ALDH was obtained as a fused protein with 6xHis polypeptide appended to the amino terminal end of the enzyme and purified by affinity chromatography [42]. The induced cells (400 mL culture) were resuspended in $20 \mathrm{~mL}$ buffer A (50 mM potassium phosphate buffer, $\mathrm{pH} 7,200 \mathrm{mM} \mathrm{KCl}, 10 \mathrm{mM}$ beta-mercaptoethanol ( $\beta-\mathrm{ME})$ ) and disrupted by ultrasonic treatment for 5 min with $5 \mathrm{~s}$ pulses and $60 \mathrm{~s}$ pauses, using a Sonopuls ultrasonic homogenizer (Bandelin, Berlin, Germany). The cellular extract was centrifuged at $16,000 \times \mathrm{g}$ for $30 \mathrm{~min}$ at $4^{\circ} \mathrm{C}$, and the soluble fraction was applied on a 1-mL Ni-NTA agarose (Qiagen, Hilden, Germany) gravity flow column equilibrated with buffer A. The column was washed with $10 \mathrm{~mL}$ buffer A, and $6 \mathrm{~mL}$ buffer A containing $100 \mathrm{mM}$ imidazole, and the recombinant F-ALDH was eluted in the presence of $250 \mathrm{mM}$ imidazole. The fractions were analyzed by electrophoresis on 12.5\% SDS-PAGE gels [43]. After the buffer exchange to $50 \mathrm{mM}$ potassium phosphate $\mathrm{pH}$ 7, $10 \mathrm{mM} \beta-\mathrm{ME}$, using the 7K MWCO Zeba Spin Desalting columns (Thermo Fisher Scientific, Massachusetts, USA), the purified enzyme was stored at $-20^{\circ} \mathrm{C}$ in the presence of $15 \%$ glycerol. Protein concentrations were measured using the Bio-Rad Protein Assay Kit II (BioRad, Wien, Austria).

The oligomeric structure of F-ALDH was determined by size exclusion chromatography using a $1 \times 50 \mathrm{~cm}$ HiLoad Superdex 200 column (G.E. Healthcare, Wien, Austria) equilibrated with $50 \mathrm{mM}$ phosphate buffer $\mathrm{pH}$ 7.0, $10 \mathrm{mM} \beta-\mathrm{ME}$. A $400 \mu \mathrm{L}$ sample of enzyme at a concentration of $1.8 \mu \mathrm{g} \mu \mathrm{L}^{-1}$ was applied on the column and eluted at a $1-\mathrm{mL} \mathrm{min}^{-1}$ flow rate. The molecular mass of F-ALDH was estimated using the molecular weight standards cytochrome $C(12,400)$, carbonic anhydrase $(29,000)$, bovine serum albumin $(66,000)$, alcohol dehydrogenase $(150,000)$, and $ß$-amylase $(200,000)$ (Sigma).

\subsection{Enzyme Assay}

F-ALDH activity was determined spectrophotometrically by measuring the rate of $\mathrm{NADH}$ formation at $\mathrm{OD}_{340 \mathrm{~nm}}$. The reaction mixture contained $1 \mathrm{mM}$ aldehyde, $1 \mathrm{mM}$ $\mathrm{NAD}(\mathrm{P})^{+}$, and $100 \mathrm{mM}$ Glycine/KOH pH 9.5 buffer with $2 \mathrm{mM} \beta-\mathrm{ME}$ in a final reaction volume of $200 \mu \mathrm{L}$. The reaction initiated by the addition of $200 \mathrm{ng}$ F-ALDH was continuously measured for $5 \mathrm{~min}$ at $25^{\circ} \mathrm{C}$ using a FLUOstarOmega microplate reader (BMG Labtech, Offenburg, Germany). One unit of enzyme was defined as the amount of enzyme catalyzing the formation of $1 \mu \mathrm{mol}$ NADH per minute, using the molar absorption coefficient $\varepsilon_{\mathrm{NADH}}=6.22 \times 10^{3} \mathrm{~L} \mathrm{~mol}^{-1} \mathrm{~cm}^{-1}$.

\subsection{Biochemical Characterization of F-ALDH}

Substrate specificity of F-ALDH was investigated using aliphatic (isovaleraldehyde, acetaldehyde, propionaldehyde, butyraldehyde, valeraldehyde) and aromatic (benzaldehyde, 4-fluorbenzaldehyde, 2-fluorobenzaldehyde, 4-isopropilbenzaldehyde) aldehydes (Acros Organics, Geel, Belgium), in the presence of cofactors NAD ${ }^{+}$(Roche, Basel, Switzerland) or NADP ${ }^{+}$(Sigma, Albuch, Germany). The effect of various compounds on the reaction rates, including salts $(100 \mathrm{mM} \mathrm{NaCl}$ and $100 \mathrm{KCl}$ in $100 \mathrm{mM}$ glycine/KOH buffer, $\mathrm{pH}$ 9.5, or $100 \mathrm{mM}$ phosphate buffer, $\mathrm{pH} 8.5)$, metal ions $\left(1 \mathrm{mM} \mathrm{Ca}^{2+}, \mathrm{Mg}^{2+}, \mathrm{Ni}^{2+}\right)$, additives (1 mM EDTA, 1-10 mM $\beta-M E, 1 \%$ Triton X-100, 1-10\% ethanol), and a 1 x protease inhibitor 
cocktail (Roche, Basel, Switzerland) were determined at $25^{\circ} \mathrm{C}$ under standard conditions. The influence of $\mathrm{pH}$ on the F-ALDH activity was assayed in the $\mathrm{pH}$ range of 6-10.5 using $100 \mathrm{mM}$ potassium phosphate ( $\mathrm{pH}$ 6.0-7.5), $100 \mathrm{mM}$ Tris ( $\mathrm{pH}$ 7.5-9) and $100 \mathrm{mM}$ glycine$\mathrm{KOH}$ (pH 9.0-10.5) buffers. The F-ALDH thermal stability was determined by incubating the enzyme for $10 \mathrm{~min}$ at various temperatures $\left(4^{\circ} \mathrm{C}, 30^{\circ} \mathrm{C}, 40{ }^{\circ} \mathrm{C}, 50{ }^{\circ} \mathrm{C}, 60^{\circ} \mathrm{C}, 70{ }^{\circ} \mathrm{C}\right)$ and assaying the residual activity at $25^{\circ} \mathrm{C}$. The effect of temperature on the reaction rate was determined by measuring the $\mathrm{NAD}^{+-}$dependent $\mathrm{ALDH}$ activity at different temperatures ranging from $4{ }^{\circ} \mathrm{C}$ to $60^{\circ} \mathrm{C}$, using $1 \mathrm{mM}$ isovaleraldehyde as a substrate.

\subsection{Kinetic Parameters}

Kinetic parameters were measured at $30^{\circ} \mathrm{C}$ by varying the concentrations of substrates benzaldehyde $(62 \mu \mathrm{M}-10 \mathrm{mM})$ and isovaleraldehyde $(16 \mu \mathrm{M}-10 \mathrm{mM})$ in the presence of $1 \mathrm{mM} \mathrm{NAD}{ }^{+} / \mathrm{NADP}^{+}$or by varying the concentration of cofactors $\mathrm{NAD}^{+}(11.5 \mu \mathrm{M}-$ $4 \mathrm{mM})$ and $\mathrm{NADP}^{+}(62.5 \mu \mathrm{M}-4 \mathrm{mM})$ in the presence of $2 \mathrm{mM}$ benzaldehyde or $375 \mu \mathrm{M}$ isovaleraldehyde. Saturation curves were fit to the Michaelis-Menten equation or to an equation comprising substrate inhibition, $v=V \max [S] /\left(K m+[S]+[S]^{2} / K i\right)$, where $K i$ is the substrate inhibition constant.

\subsection{Sequence Analyses and Phylogeny}

The primary structure analysis of F-ALDH was carried out using the ExPASy ProtParam tool [44] to calculate the theoretical molecular weight (MW), isoelectric point (pI), aliphatic index, and grand average of hydropathicity (GRAVY). The identity and similarity percentages of F-ALDH with homologous enzymes were determined using the Emboss Needle pair alignment tool (http:/ / www.ebi.ac.uk/Tools/psa/emboss_needle/ [45]. Protein multiple alignment was carried out using the CLUSTAL OMEGA EMBL-EBI (1.2.4) software http: / /www.ebi.ac.uk/Tools / msa/clustalo/) [45].

Phylogenetic analysis was performed using the MEGAX software [46]. The MUSCLE algorithm in the MEGA package was used to align the primary structure of ALDHs obtained from the GenBank database after eliminating all positions containing gaps and missing data. The consensus phylogenetic tree was obtained by maximum-likelihood analysis of 70 amino acid sequences with a total of 411 positions in the final dataset [47]. Initial trees for the heuristic search were obtained by applying Neighbor-Join and BioNJ algorithms to a matrix of pairwise distances using a JTT model [48] and selecting the topology with the superior log likelihood value. A discrete Gamma distribution was used to model evolutionary rate differences among sites (five categories $(+G$, parameter $=0.6872)$ ). The tree topography was evaluated using the bootstrap analysis of 1000 repetitions.

\section{Results}

\subsection{Phylogeny and Sequence Analyses of F-ALDH}

BLAST screening of the Flavobacterium PL002 genome sequence [40] led to the identification of a 1506-bp ald $H$ gene coding for an open reading frame homologous to bacterial aldehyde dehydrogenases (accession number MH542427). The hypothetical enzyme (FALDH) consisted of 501 amino acids, with calculated mass of $54.95 \mathrm{kDa}$ and theoretical pI of 5.87 .

The phylogenetic analysis (Figure 1) of the F-ALDH amino acid sequence in relation with the homologous aldehyde dehydrogenases from Flavobacterium spp. and other genera showed the Antarctic enzyme grouped with ALDSs from the Clade I of the genus Flavobacterium. F-ALDH appeared to be a close homolog (93.7\%) of aldehyde dehydrogenases from the psychrotrophic F. frigoris [WP 007139093.1] originating from Antarctic lakes [49] and mesophilic F. granuli [WP 072945862.1] retrieved from wastewater [50]. 


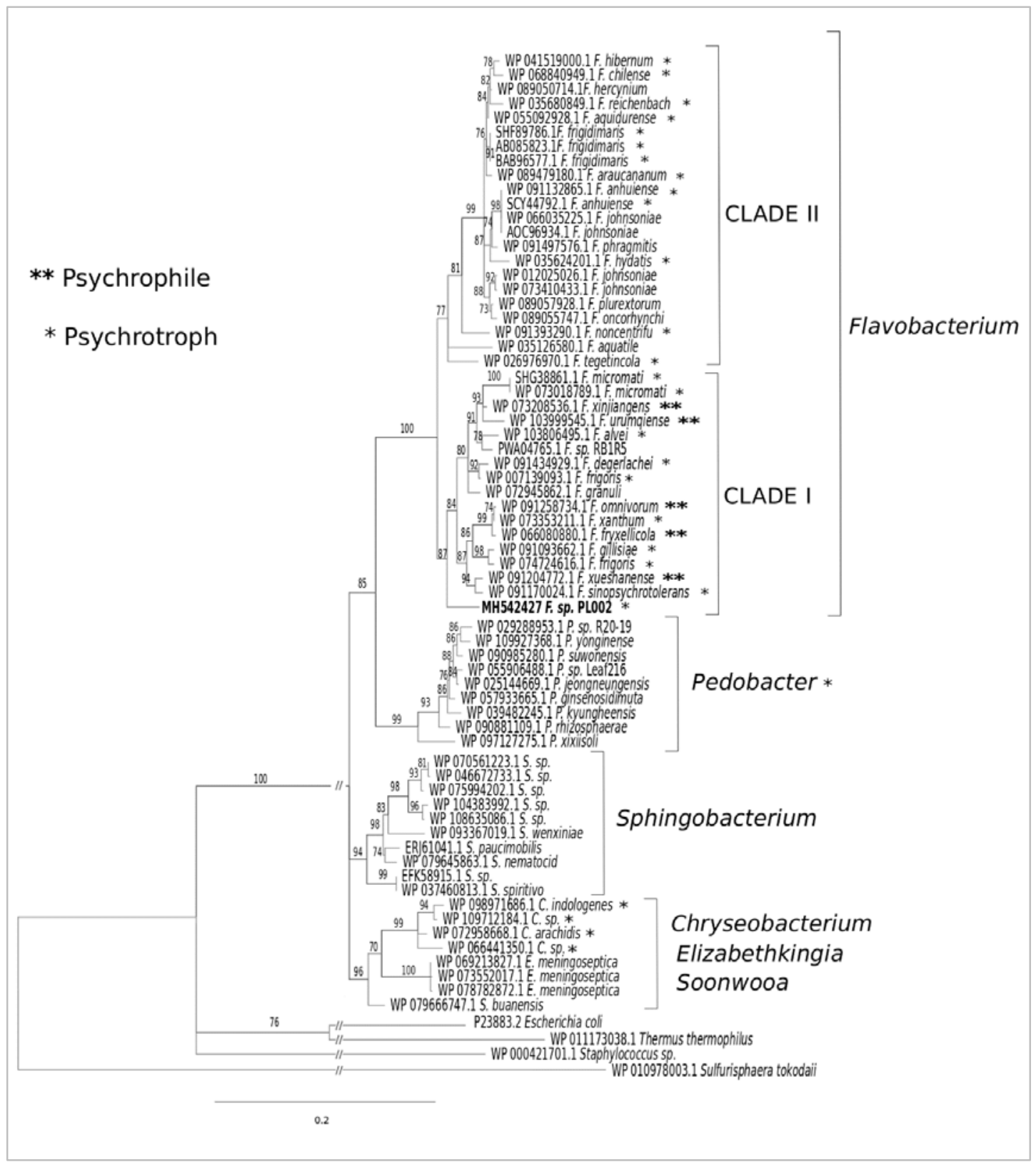

Figure 1. Phylogenetic tree of ALDH primary sequence. The amino acid sequence of ALDH from Flavobacterium PL002 and other psychrotrophic and psychrophilic Flavobacterium, Pedobacter, and Cryseobacterium species with indicated accession numbers were used for the phylogenetic tree construction, using the Sulfurisphaera tokadaii [WP_010978003.1] protein sequence as the outgroup. Numbers at branches represent percentages of bootstrap support (1000 resampled datasets) based on maximum-likelihood. The tree is drawn to scale, with branch lengths measured in the number of substitutions per site. $\left(^{*}\right)$ psychrotrophic species; $\left(^{* *}\right)$ psychrophilic species.

This enzyme was also closely related (92.5\%-92.9\%) to ALDH from different coldenvironments, including F. frigoris [WP 074724616.1] and F. degerlachei [WP 091434929.1] from Antarctic lake water, F. alvei [WP 103806495.1] from a freshwater river, F. gillisiae [WP 091093662.1] from Antarctic sea ice, F. xanthum [WP 073353211.1] from an Antarctic mud pool, and F. omnivorum [WP 091258734.1] from China No. 1 glacier [49,51,52]. Among the two well-supported Flavobacterium subclades, F-ALDH was associated with the F. xinjiangens [WP07328536.1] enzyme from clade I, the only psychrophilic strains identified so far from this genus, and F. omnivorum [WP 091258734.1], F. urumqiense [WP103999545.1], 
and F. xueshanense [091204772.1] isolated from frozen soil and glacier ice, respectively [28,53]. Other ALDHs constituting relatively closely related homologs $(90.27 \%-91.00 \%)$ originated from the psychrotrophic Pedobacter (90.51\%-91.00\%) and Chryseobacetrium (90.02\%-91.00\%) species, and mesophilic genera Sphingobacterium, Elizabethkingia, and Soonwooa, while Escherichia coli [P23883.2] [54], Staphylococcus sp. [WP_000421701.1] [46], and Thermus thermophilus [WP011173038.1] [55] enzymes represented more distant homologs (Figure 1). The archaeal ALDH [WP_010978003.1] from Sulfurisphaera tokadaii [56] was used as a rooting enzyme for the bacterial ALDH phylogenetic tree, marking a larger structural divergence based on the microbial kingdom.

The deduced amino acid sequence of F-ALDH is homologous with ALDH from the Antarctic isolate Flavobacterium frigidimaris [BAB96577.1] [39], showing 89\% identity and $94 \%$ similarity with this psychrophilic counterpart and showing lower scores (38-39\% identity, 56-60\% similarity) with ALDHs from mesophilic bacteria Escherichia coli [Heim 1991] and Staphylococcus aureus [46], and thermophilic Thermus thermophilus [55] (Table 1$)$. The lowest identity (30\%) and similarity (52\%) was obtained with the hyperthermophilic Sulfurisphaera tokodaii archaeal ALDH [56] (Table 1). These differences in similarity levels of ALDHs primary structures suggested the presence of structural adaptation elements of enzymes from cold environments to ensure an equilibrium among their activity, stability, and flexibility required for catalysis low temperatures [57].

Table 1. F-ALDH sequence similarity of F-ALDH to aldehyde dehydrogenases.

\begin{tabular}{|c|c|c|c|c|c|c|c|}
\hline \multirow{2}{*}{\multicolumn{2}{|c|}{ ENZYME }} & \multicolumn{6}{|c|}{ Identity (\%) } \\
\hline & & F-ALDH & Ff-ALDH & Ec-ALDH & Sa-ALDH & Tt-ALDH & St-ALDH \\
\hline F-ALDH & \multirow{6}{*}{ 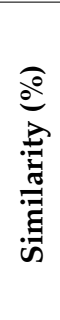 } & & 89 & 38 & 38 & 39 & 30 \\
\hline Ff-ALDH & & 94 & & 38 & 38 & 39 & 30 \\
\hline Ec-ALDH & & 56 & 57 & & 37 & 42 & 33 \\
\hline Sa-ALDH & & 60 & 59 & 58 & & 37 & 34 \\
\hline Tt-ALDH & & 58 & 57 & 60 & 57 & & 33 \\
\hline St-ALDH & & 52 & 52 & 56 & 58 & 54 & \\
\hline
\end{tabular}

Sequence identity and similarity percentage of ALDHs from the psychrotrophic Flavobacteriun PL002 (F-ALDH) and psychrophilic Flavobacterium frigidimaris (Ff-ALDH), mesophilic Escherichia coli (Ec-ALDH), Staphylococcus aureus (Sa-ALDH), and (hyper)thermophilic Thermus thermophilus (Tt-ALDH) and Sulfolobus tokodaii (St-ALDH) were calculated from pairwise alignments of proteins using Emboss Needle software.

Multiple alignment of these aldehyde dehydrogenases (Figure 2) highlighted the presence in F-ALDH of all residues involved in catalysis and substrate binding universally conserved in ALDHs [24,58,59], confirming that this Antarctic enzyme is a functional aldehyde dehydrogenase. Among these conserved residues, Cys296, Glu257, G293, and N160 (F-ALDH numbering) were shown to play a role as a catalytic nucleophile (Cys296) and base (Glu257), in the orientation of Cys residue (Gly293), and in stabilizing the aldehyde carbonyl oxygen (Asn160) during catalysis [60]. Gly259-Gly260 dipeptide appeared to stabilize the interface between the catalytic and cofactor binding domains [32]. The 12residue specific motif (marked with stars) comprising Arg75, Gly151, Asn160, Pro162, Gly177, Lys183, Gly259, Cys296, Pro401, Gly447, Asn452, and Gly465 is also conserved in FALDH. Glycine residues are in a high percentage (8.6\%) and positioned in critical turns [60]. Also, among the 21 residues that could be involved in substrate binding, conserved residues are located in the substrate binding site (Asn157, Trp165, Lys166, and Leu418 in ALDH from S. aureus) and in the cofactor binding site (Trp156, Lys180, Gly233, Glu390, and Phe392 in ALDH from S. aureus), while Gly233 and Phe392 are responsible for binding the NAD nicotinamide ring [60]. Asn157 could stabilize the active cysteine during catalysis [61,62], and Trp156 and Lys180 situated in a hydrophobic pocket interacts with $\mathrm{NADP}^{+}[59,62]$. 


\begin{tabular}{|c|c|c|}
\hline & & \\
\hline F-ALDH & ----1 MGNIAQRPEFKAKYDNY IGGKFVAPI KGNYFDVVSPIDGKVFTQAAH & 47 \\
\hline Ff-ALDH & $----1-1-$ MSNTIQRPEFKAKYDNY INGKFTAPVKGEYFDVLSPIDGKVFTKAAH & 47 \\
\hline Sa-ALDH & 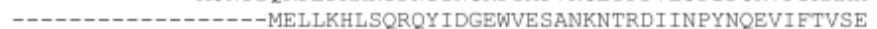 & 42 \\
\hline EC-ALDH & MNFHH---LAYWQDK----ALLSLAIENRLF INGEYTAAAENETFETVDPVTQAPLAKIAR & 53 \\
\hline Tt-ALDH & MRYADRVAGISWET IEEVRRRLKERPALHF IAGEFVPSESGETFPSLDPATNEVLGVAAR & 60 \\
\hline St-ALDH & 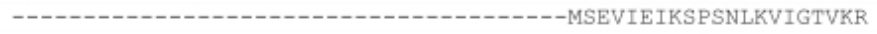 & 21 \\
\hline & $\begin{array}{llll} & : & { }^{*} & :\end{array}$ & \\
\hline F-ALDH & SSIEDLELAVDTAHKAFE--TWGKTSATERSNLLNKIAQKIEDNLEYIATVETVDNGKAI & 105 \\
\hline Ff-ALDH & SGKEDLELAVDAAYEAFK--TWGKTSVTERS ILLNKIAQKIEDNLEYIATVETIDNGKPI & 105 \\
\hline Sa-ALDH & GTKEDAERAI LAARRAFESGEWSQETAETRGKKVRAIADKIKEHREALARLETLDTGKTL & 102 \\
\hline EC-ALDH & GKSVDIDRAMSAARGVFERGDWSLSSPAKRKAVLNKLADLMEAHAEELALLETLDTGKPI & 113 \\
\hline Tt-ALDH & GGEREVDRAAKAAHEAFQ--RWSRTKAKERKRYLLRIAELIEKHADELAVMECLDAGQVL & 118 \\
\hline St-ALDH & MSKDEVRGEIEEAYKGFE--TISRMPLYKRTAILRKVSEILEREQERLARLLAMEAGKPI & 79 \\
\hline & 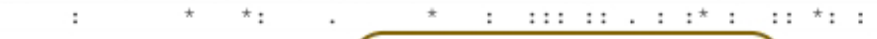 & \\
\hline F-ALDH & RETLAADIPLAIDHFRYFAGVIRAEESS-I----. & 156 \\
\hline Ff-ALDH & RETLAADIPLAIDHERYFAGVIRAEESS-I-------AELDSQTVSIALSEPI GVVAO I & 156 \\
\hline Sa-ALDH & EES-YADMDDIHNVFMYFAGLADHDGGEMI-------DSPIPDTESKIVKEPVGVVTd & 153 \\
\hline $\mathrm{EC}-\mathrm{ALDH}$ & RHSLRDDI PGAARAIRWYAEAIDA VYGEVA---------TTSSHELAMIVRE PV GVIAAI & 164 \\
\hline Tt-ALDH & RIV-RAQVARAAENEAFYAEYAEH AMEDRT--------FPVDRDWLYYTVRVPA GPVGII & 169 \\
\hline St-ALDH & KDS-RVEVMRASRLFRQA.AEEAAA IVLEGKNYRVDAYEYPPGNENRIVISTREPIGVVTA I & 138 \\
\hline & 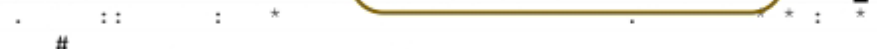 & \\
\hline F-ALDH & IPWNFPILMAVAKIAPALA.AGNTVVIKEAESTPISILVLMELIG-DILPPGVLNIVNGFG & 215 \\
\hline Ff-ALDH & IPWNEPILMAVWIAPALARGNTIVIKFAESTPISILVLMELIG-DILPPGVLNIVNGFG & 215 \\
\hline Sa-ALDH & PSE ITPLTT IRVFE LMEEVGFPKGTINLILGAG & 213 \\
\hline EC-ALDH & VPWNFPLLLTCWKLGPALAAGNSVIIKESEKSPLSAIRLAGLAKEAGLPDGVLNVVTGFG & 224 \\
\hline Tt-ALDH & TPWNAPLMLST RIAPALAFGNTVVI R AENSPFTATKLAEI LKEADLPPGVFNLVQGFG & 229 \\
\hline St-ALDH & LPFNFPINSFAHKVAPAIAVGNSVVVKFSISTPLSAIEMKKILVEAGLPDSAVRIVTGYS & 198 \\
\hline & 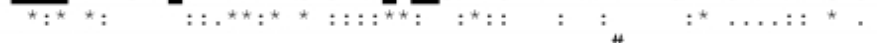 & \\
\hline F-ALDH & AELGRALVTNKKVSKAAFTGSTITGRLVMQYATE-NIIPVTIELGGKSPNIFMKSVGDAD & 274 \\
\hline Ff-ALDH & AELGRPLVTNKKVAKAA ETGSTT GRLVMQYATE-NIIPVTIELGGKSPNIFFPSVADHD & 274 \\
\hline Sa-ALDH & SEVGDVMSGHKEVDLVSFTGG IEIGKHIMKNAAN-NVTNIAIELGGKNPNI IFDDA-DFE & 271 \\
\hline EC-ALDH & HEAGQALSRHNDIDAIAFTGSTR GKLLKDAGDSNMKRVWIEAGGSANIVFADCPDLQ & 284 \\
\hline Tt-ALDH & EEAGA.ALVAHPLVPLITLTGETEIGK IVMRNA.AD-HLKRLSPELGGKSPALVFADA-DLE & 287 \\
\hline St-ALDH & NEIGDELITHPLVGLITLTGSTRGIAIASKAVS-LGKRIIMELGGSDPIIVLEDA-NID & 256 \\
\hline & 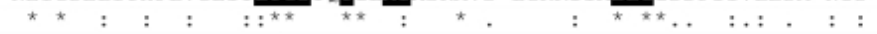 & \\
\hline & \#\# \# & \\
\hline F-ALDH & DDFFDKAIEGAVLFA NQGEICTSPSRLLVHEDIYEKFMARVIERTKAIKMGNPLDRTTM & 334 \\
\hline Ff-ALDH & DDFFDKAIEGAVLFALNQGEICTCPSRLL I HEDIYEKF IARVIERTEAI IAGNPLDKSTM & 334 \\
\hline Sa-ALDH & LAVD----QALNGGYFHAGQVCSAGSRILVQNSIKDKFEQALIDRVKKIKLGNGFDADTE & 327 \\
\hline EC-ALDH & QAAS----ATAAGIFYNQGQVCIAGTRLLLEESIADEFLALLKQQAQNWQPGHPLDPATT & 340 \\
\hline TE-ALDH & RALD----AVVFQIFSFNGERCTASSRLLVEEKIFEDFVGKVVERARAIRVGHPLDPETE & 343 \\
\hline St-ALDH & RASS----IAVRARYEYAGQNCNAGKRIIVREEIYDKFVKAFKEKVKALKVGDPLDESTD & 312 \\
\hline & ${ }^{\star}:{ }^{\star} \cdot .^{\star}::::_{*}{ }^{\star}: .^{\star} \quad .:: \ldots{ }^{\star} \cdot:^{\star}{ }^{\star}$ & \\
\hline F-ALDH & YK---MDGDLAGGYYIQPTIFKGN-NK & 390 \\
\hline Ff-ALDH & IGAQTSLVQKEKIMSYIKLGKEEGAELLTGGDENH---LGGDLEGGYYIKPTLFKGH-NK & 390 \\
\hline Sa-ALDH & MGPVISTEHRNKIESYMDVAKAEGATIAVGGKRPD----RDDLKDGLFFEPTVITNCDTS & 383 \\
\hline EC-ALDH & MGTLIDCAHADSVHSFIREGESKGQLLLDGRNAGL----------AAAIGPTIFVDVDPN & 390 \\
\hline Tt-ALDH & VGPLIHPEHLQRVLGYVEAGKREGARLLVGGERAKTSFRGEDLSRGNYLLPTVFVGE-NH & 402 \\
\hline St-ALDH & IGPVINQESVEKLNKALEDAQSKGGNVEVLN---------KGPETGYFFPLSLVTNPSLD & 363 \\
\hline & $:^{\star} \quad: \quad: \quad: \quad:::^{\star} \quad:$ & \\
\hline F-ALDH & MRIFQEEIFGPLAVTTFKTTEEAIAIANDTMYG GAGLWTRDAHEIYQVPRAIQAGRVW & 45 \\
\hline $\mathrm{Ff}-\mathrm{ALDH}$ & MRIFQE I GPVLAVTTFKTTEEAIE IANDTMYG GAGVWTRDAHEIYQVPRAIQSGRVW & 45 \\
\hline Sa-ALDH & MRIVQE V GPVVTVEGFETEQEAIQLANDS IYG AGAVESKDIGKAQRVANKLKLGTVW & 443 \\
\hline EC-ALDH & ASLSREEI GPVLVVTRFTSEEQALQLANDSQYG GAAVWTRDLSRAHRMSRRLKAGSVF & 450 \\
\hline Tt-ALDH & MKIAQE高IGPVLVAIPFKDEEEALRKANDTKYG A.AYVETRDLERAHRLALELEAGMVY & 462 \\
\hline St-ALDH & MLVLKTEI GGIAPIVSVKSDEEAINIANSTEYGESAIFSNDVNRALKIAKELKFGAII & 423 \\
\hline & 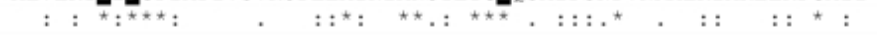 & \\
\hline F-ALDH & 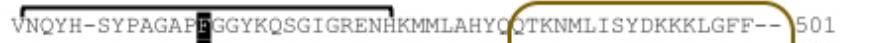 & \\
\hline Ff-ALDH & INQYH-SYPAGAPEGGKQSGIGRENHKMMLGQYF QTKNMLISYDKKKLGEF-- 501 & \\
\hline Sa-ALDH & INDFH-PYFAQAFW GGYKQSGIGRELGKEGLEEYIVSKHILTNTNPQLVNWFSK 496 & \\
\hline EC-ALDH & 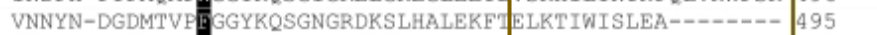 & \\
\hline Tt-ALDH & LNSHN-VRHLPT A GGVKGSGDRREGGTYALDFYT DLKTIALPLRPPHVPKFGK 515 & \\
\hline St-ALDH & INDSTRLRWDSLFGGGKKTGIGREGVRDTMLEMTENKLIAITLL--------- 468 & \\
\hline & $: * . \quad * * * * *:^{*} *: \quad: \quad \underbrace{*}:$ & \\
\hline
\end{tabular}

Figure 2. Multiple alignment of ALDH primary structure from psychrophilic, mesophilic, and thermophilic bacteria. Comparison of Flavobacterium PL002 F-ALDH [MH542427] with the homologous enzymes from the psychrophilic F. frigidimaris [AB085823], mesophilic S. aureus [WP_000421701.1] and E. [P23883.2], thermophilic T. thermophilus [WP_011173038.1], and hyperthermophilic archaeon S. tokodaii [WP_010978003.1]; identical (stars) and conserved (dots) residues from all enzymes; active site residues (grey shade); $\mathrm{NAD}^{+} / \mathrm{NADP}^{+}$cofactor binding site residues (black shade); aldehyde dehydrogenase motifs (PROSITE entry PS00687and PS00070) (boxes). 
An ion pair conserved in all tetrameric ALDHs could be formed in F-ALDH between the homologous Lys166-Glu467 (in S. aureus) in support of the determined oligomeric structure (tetramer) of the cold-active F-ALDH. Moreover, this multiple alignment revealed a partial conservation of the F-ALDH oligomerization domain, mainly with that of F. frigidimaris $\mathrm{ALDH}$, consisting of two regions $\left(\mathrm{I}_{127}-\mathrm{L}_{150}\right.$ and $\left.\mathrm{Q}_{485}-\mathrm{F}_{501}\right)$ (Figure 2). Among these, the $\mathrm{I}_{127}-\mathrm{L}_{150}$ stretch showed a high content of Ser (25\%) and Glu (16\%) residues, and a 5:1 ratio of negatively to positively charged residues. The calculated hydropathicity GRAVY index (0.208) of this region indicated the hydrophobic nature of the F-ALDH subdomain, similar to E. coli ALDH (0.133) and distinct from the rest of the investigated ALDH homologs (negative values). The amino acid composition corresponded to an aliphatic index of 130, indicating an increased thermal stability. The second region $\left(\mathrm{Q}_{485}-\mathrm{F}_{501}\right)$ was rich in positively charged residues Lys (23.5\%) and hydrophobic residues Leu and Phe (11\% each). However, the ratio of negatively to positively charged amino acids was reversed in this case (1:4), and the negative GRAVY index (-0.571) corresponded to a hydrophilic region with a low aliphatic index (68.8).

\subsection{Cloning, Expression and Purification of F-ALDH}

The gene coding for F-ALDH was inserted in the pHAT2 expression vector that appended a His-tag at the N-terminal of the recombinant enzyme to facilitate purification. The resulted construct (pF-ALDH) was expressed in E. coli at a level of $45 \mathrm{mg} \mathrm{L}^{-1}$ of culture, and the soluble fraction was purified to near homogeneity in one step by affinity chromatography on Ni-NTA agarose resin after elution with $250 \mathrm{mM}$ imidazole (Figure 3). The estimated molecular mass of the recombinant F-ALDH by SDS-PAGE was $\sim 55 \mathrm{kDa}$, in accordance with the calculated one. Under nondenaturing conditions, the size of the molecule determined by size exclusion chromatography on a HiLoad Superdex 200 column corresponded to a single peak of $210 \mathrm{kDa}$ (not shown), indicating a homotetrameric enzyme, a commonly found oligomeric structure in class 1 and class 2 members of ALDHs [63,64].

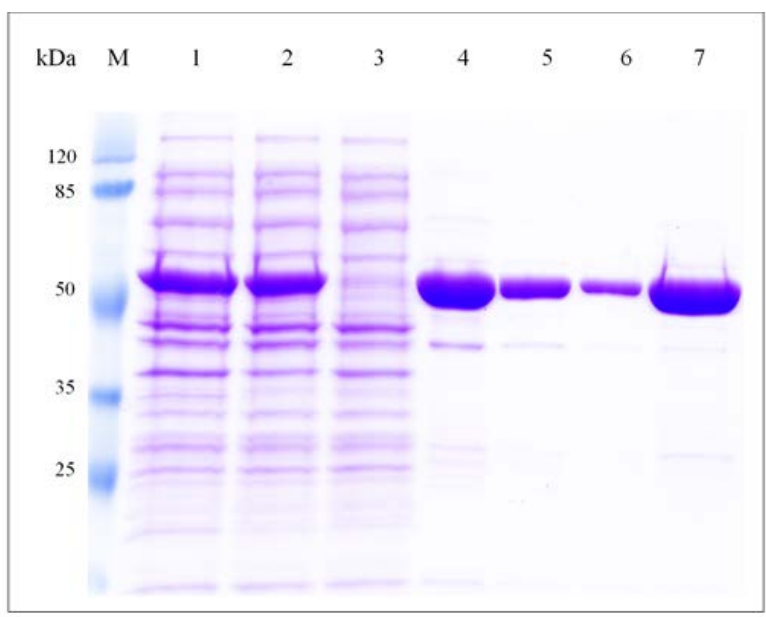

Figure 3. Purification of F-ALDH. Recombinant F-ALDH was purified to homogeneity using $\mathrm{Ni}^{2+}$ affinity chromatography as indicated in Methods and monitored by SDS-PAGE. (M): standard proteins of known molecular mass (Thermo Scientific); (1) total extract obtained by induction of $100 \mathrm{~mL}$ culture of E. coli BL21(DE3) transformed with pF-ALDH; (2) cell-free extract (soluble fraction) applied onto Ni-NTA agarose affinity column; (3) washing fraction in buffer A (50 mM potassium phosphate, pH 7.0, $200 \mathrm{mM} \mathrm{KCl}, 10 \mathrm{mM} \beta-\mathrm{ME})$; (4-6) elution fractions of recombinant F-ALDH in buffer A containing $250 \mathrm{mM}$ imidazole; (7) desalted F-ALDH in buffer A.

\subsection{Biochemical Characterization of F-ALDH}

Substrate specificity of the cold-active F-ALDH was screened for a broad spectrum of aldehydes comprising six aliphatic and four aromatic aldehydes in the presence of $\mathrm{NAD}^{+}$or $\mathrm{NADP}^{+}$as cofactors (Figure 4). For all tested substrates, the activity of this 
cold-active enzyme indicated an overall preference for the $\mathrm{NAD}^{+}$-dependent reaction. Among aldehydes, the highest $\mathrm{NAD}^{+}$-dependent activity was measured when using 4-isopropilbenzaldehyde $\left(18.9 \pm 0.7 \mathrm{U} \mathrm{mg}^{-1}\right)$ and isovaleraldehyde for the $\mathrm{NADP}^{+}$dependent reaction $\left(22.6 \pm 1.2 \mathrm{U} \mathrm{mg}^{-1}\right)$ (Figure 4$)$. A high (86.8\%) NAD-dependent activity was also observed when using isovaleraldehyde and butiraldehyde (60.5\%) for the NADPdependent reaction. These aldehydes are known as flavoring agents for the food and beverage industries, and 4-isopropilbenzaldehyde (cuminaldehyde) is also used in cosmetics [65]. Benzaldehyde is known to form covalent linkages to lysine amino groups with an inhibitory effect on this class of enzymes [66]. However, in the case of F-ALDH, the substrate specificity suggested an independent response on the type of aldehyde (aliphatic or aromatic) used in the reaction (Figure 4). Also, the major difference observed for the catalysis of benzaldehyde and the 2-isopropyl and 4-isopropil derivates of this aromatic substrate (Figure 4) is in accordance with the specificity variation within the structurally heterogeneous group of benzaldehyde compounds [67]. In this sense, further 3D modeling and molecular docking analyses could highlight subtle structural features responsible for the substrate specificity of both substrates and cofactors used by this cold-active ALDH.

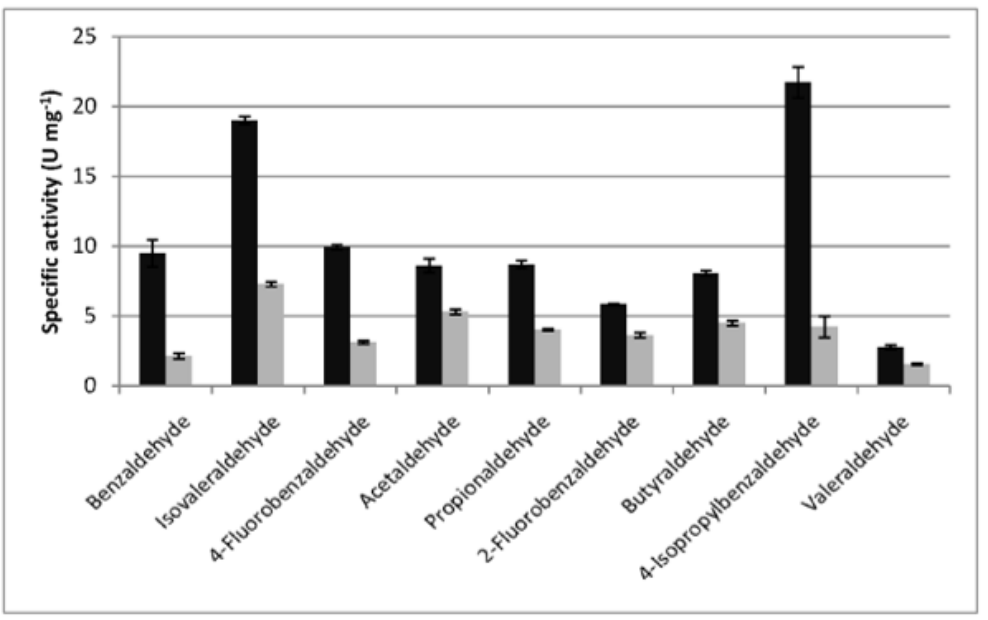

(A)

\begin{tabular}{l|cc}
\hline \multicolumn{1}{c}{ SUBSTRATE } & \multicolumn{2}{c}{ Relative activity (\%) } \\
\cline { 2 - 3 } & NAD $^{+}$ & NADP $^{+}$ \\
\hline 4-Isopropylbenzaldehyde & 100.0 & $52.2 \pm 2.5$ \\
Isovaleraldehyde & $86.8 \pm 0.2$ & 100.0 \\
4-Fluorobenzaldehyde & $45.8 \pm 0.8$ & $42.2 \pm 0.6$ \\
Benzaldehyde & $41.2 \pm 1.1$ & $27.7 \pm 0.8$ \\
Propionaldehyde & $40.0 \pm 1.3$ & $55.3 \pm 1.0$ \\
Acetaldehyde & $38.4 \pm 0.8$ & $71.5 \pm 2.0$ \\
Butyraldehyde & $37.2 \pm 0.8$ & $60.5 \pm 0.3$ \\
2-Fluorobenzaldehyde & $26.9 \pm 0.2$ & $48.4 \pm 0.6$ \\
Valeraldehyde & $12.8 \pm 0.8$ & $21.4 \pm 1.1$ \\
\hline
\end{tabular}

(B)

Figure 4. Substrate specificity of F-ALDH. (A) The specific activity of F-ALDH was measured at $25{ }^{\circ} \mathrm{C}$ as indicated in Methods, using $1 \mathrm{mM}$ aliphatic aldehydes (isovaleraldehyde, acetaldehyde, propionaldehyde, butyraldehyde, valeraldehyde) and aromatic aldehydes (benzaldehyde, 4-fluorobenzaldehyde, 2-fluorobenzaldehyde, or 4-isopropylbenzaldehyde) as substrates, in the presence of $1 \mathrm{mM} \mathrm{NAD}^{+}$and $1 \mathrm{mM} \mathrm{NADP}^{+}$. (B) Relative activity (\%) was calculated considering $100 \%$ when using 4 - isopropylbenzaldehyde $\left(\mathrm{NAD}^{+}\right)$and isovaleraldehyde $\left(\mathrm{NADP}^{+}\right)$, respectively. 
The influence of metal ions and various additives on the NAD-dependent activity showed an overall stable response when using benzaldehyde as a substrate (Table 2). A moderate activity loss (18-22\%) was observed in the presence of the protease inhibitor. Meanwhile, the addition of $10 \%$ ethanol or betamercaptoethanol ( $\beta$-ME) induced a slight activation up to $144.7 \%$ and $124.1 \%$, respectively (Table 2 ).

Table 2. Influence of different compounds on F-ALDH activity.

\begin{tabular}{cc}
\hline Compound & Relative Activity (\%) \\
\hline None & 100 \\
$\mathrm{KCl}(100 \mathrm{mM})$ & 104.5 \\
$\mathrm{NaCl}(100 \mathrm{mM})$ & 102.2 \\
$\mathrm{KCl}(100 \mathrm{mM})^{*}$ & 99.6 \\
$\mathrm{NaCl}(100 \mathrm{mM})^{*}$ & 111.3 \\
$\mathrm{CaCl}(1 \mathrm{mM})$ & 93.5 \\
$\mathrm{MgSO}_{4}(1 \mathrm{mM})$ & 91.2 \\
$\mathrm{MgCl}_{2}(1 \mathrm{mM})$ & 84.4 \\
$\mathrm{NiCl}_{2}(1 \mathrm{mM})$ & 78.6 \\
$\mathrm{HgCl}_{2}(0.5 \mathrm{mM})$ & 0 \\
$\mathrm{HgCl}_{2}(1 \mathrm{mM})$ & 0 \\
$\mathrm{Ethanol}^{*}(1 \%)$ & 85.0 \\
Ethanol $(10 \%)$ & 144.7 \\
EDTA $(2 \mathrm{mM})$ & 81.7 \\
Triton $\mathrm{X}-100$ & 90.1 \\
$\beta-M E(1 \mathrm{mM})$ & 116.1 \\
$\beta-M E(10 \mathrm{mM})$ & 124.1 \\
Protease inhibitors $(1 \mathrm{X})$ & 78.2
\end{tabular}

The ALDH activity measured at $25{ }^{\circ} \mathrm{C}$ for $5 \mathrm{~min}$ using $200 \mathrm{ng}$ F-ALDH, $50 \mathrm{mM}$ glycine buffer, $\mathrm{pH} 9.5$ $1 \mathrm{mM}$ benzaldehyde and $1 \mathrm{mM} \mathrm{NAD}^{+}$in the absence of any additive represented $100 \%$ activity, corresponding to $11.35 \mathrm{U} \mathrm{mg}^{-1} .\left(^{*}\right)$ phosphate buffer, $\mathrm{pH} 8$; ( $\beta$-ME): beta-mercaptoethanol; protease inhibitors cocktail (Roche, Basel, Switzerland).

Unlike potassium and sodium ions that had no impact on F-ALDH activity, even at $100 \mathrm{mM}$ concentrations and at different $\mathrm{pH}$ values (8 and 9.5), the tested divalent ions appeared to inhibit this cold-active enzyme (Table 2). At $1 \mathrm{mM}$ concentration, $\mathrm{Ca}^{2+}$ seems to have a lower inhibitory effect $(7 \%)$ than $\mathrm{Mg}^{2+}(9-15 \%)$, and $\mathrm{Ni}^{2+}(22 \%)$, while $\mathrm{HgCl}_{2}$ produced total inhibition independent of the concentration used (Table 2).

Reducing agents are important in ALDH activity since the catalytic site is a Cys residue. Therefore, $\beta-\mathrm{ME}$ was tested to determine the impact of this compound on FALDH, inducing a 16-24\% activation. Moderate inhibition was also produced by $2 \mathrm{mM}$ EDTA (20\%) inhibition and triton X-100 (10\%) (Table 2).

The effect of ethanol on the enzymatic activity was also tested since this solvent was used for solubilizing the aldehyde substrates. In this case, the presence of $1 \%$ ethanol induced a slight inhibition (15\%), whereas the addition of $10 \%$ ethanol increased the activity by $40 \%$ (Table 2), an effect possibly due to a putative alcohol oxidative reaction catalyzed by F-ALDH.

Optimum $\mathrm{pH}$ for the F-ALDH reaction was 9.5 when using $50 \mathrm{mM}$ glycine- $\mathrm{KOH}$ buffer, showing a 100-fold increase in the pH 6-9.5 interval and a decline for more alkaline values (Figure 5). As expected, the enzyme was inactivated at $\mathrm{pH}$ 6, a value close to the calculated pI (5.8) of this enzyme. At the same $\mathrm{pH}$ (9), the nature of the buffer also played a role on the F-ALDH activity, while the activity was reduced by $25 \%$ in the presence of Tris $\mathrm{HCl}$ as compared to glycine- $\mathrm{KOH}$ at the same concentration $(50 \mathrm{mM})$. No activity was measured at pH 2 and $\mathrm{pH} 3$ when using $50 \mathrm{mM}$ Glycine- $\mathrm{HCl}$ buffer (data not shown).

The thermal stability of the recombinant F-ALDH was determined by incubating the enzyme at various temperatures up to $70{ }^{\circ} \mathrm{C}$ and assaying the activity at $25^{\circ} \mathrm{C}$. The enzyme exhibited a high stability up to $55^{\circ} \mathrm{C}$, with a $60 \%$ apparent activation in the $40{ }^{\circ} \mathrm{C}-50{ }^{\circ} \mathrm{C}$ interval, and a $60 \%$ residual activity at $60{ }^{\circ} \mathrm{C}$ (Figure $6 \mathrm{~A}$ ). At $70{ }^{\circ} \mathrm{C}$ the enzyme was completely inactivated. At $50{ }^{\circ} \mathrm{C}$, the highest temperature favoring an active conformation, 
a prolonged incubation of the purified F-ALDH (Supplementary Figure S1) for up to $3 \mathrm{~h}$ showed a progressive partial inactivation down to $48-50 \%$ after $2 \mathrm{~h}$, possibly due to oligomers dissociation.

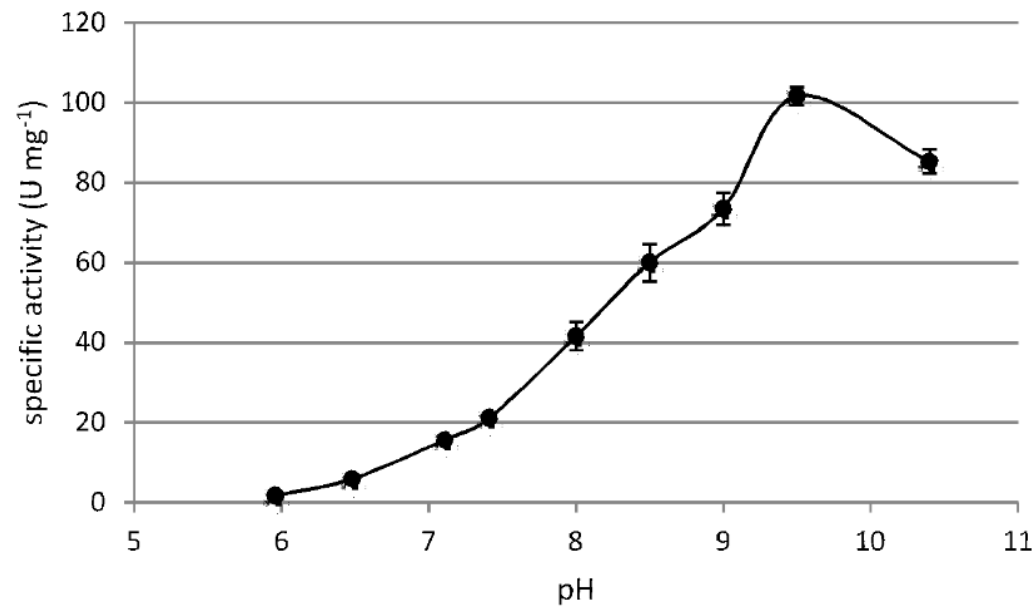

Figure 5. $\mathrm{pH}$ effect on the F-ALDH activity. The ALDH activity was measured at $25^{\circ} \mathrm{C}$ in the presence of $1 \mathrm{mM}$ benzaldehyde, $1 \mathrm{mM} \mathrm{NAD}^{+}$and $100 \mathrm{mM}$ potassium phosphate buffer ( $\mathrm{pH}$ 6.0-7.5), TrisHCl buffer ( $\mathrm{pH} 7.5-9)$, and glycine-KOH buffer ( $\mathrm{pH} 9.0-10.5)$, using $0.2 \mu \mathrm{g}$ of F-ALDH.

When stored at $4{ }^{\circ} \mathrm{C}$ for a longer period of time, the $\mathrm{NAD}^{+}$-dependent reaction appeared to be completely stable for four days, following a slight decrease (of $8 \%$ ) after seven days and of $25 \%$ after eighteen days of incubation (Figure 6B). Meanwhile, the NADP-dependent reaction was more affected, with $28 \%$ and $35 \%$ activity loss after seven and eighteen days, respectively (Figure 6B). This high stability of the enzyme, especially at low temperatures, was in accordance with the environmental conditions for the Antarctic Flavobacterium sp. PL002 growth [40].

The effect of temperature on the reaction rate of F-ALDH was determined by measuring the $\mathrm{NAD}(\mathrm{P})$-dependent activity at various temperatures (Figure $6 \mathrm{C}$ ). The temperature appeared to favor the F-ALDH reaction in the presence of the $\mathrm{NAD}^{+}$cofactor of up to four-fold higher at $50{ }^{\circ} \mathrm{C}$. However, the cold-active F-ALDH had the same activity at $13^{\circ} \mathrm{C}$, independent of the cofactor used, corresponding to the environmental temperature of this bacterial strain. The Arrhenius plot (inset-Figure 6C) was biphasic for both NADand NADP-dependent reactions, suggesting a conformational change occurring at $30^{\circ} \mathrm{C}$. The calculated activation energy using $\mathrm{NAD}^{+}$as a cofactor shifted from $76 \mathrm{~kJ} \mathrm{~mol}^{-1}$ at $4-30{ }^{\circ} \mathrm{C}$ to $19 \mathrm{~kJ} \mathrm{~mol}^{-1}$ at a higher temperature $\left(30-60{ }^{\circ} \mathrm{C}\right)$ interval, and from $53 \mathrm{~kJ} \mathrm{~mol}^{-1}$ to $11 \mathrm{~kJ} \mathrm{~mol}^{-1}$ between the same temperature intervals in the case of the $\mathrm{NADP}^{+}$-dependent reaction. This shift, indicating temperature-dependent changes in the catalytic mechanism, was also observed in ALDH from other psychrophilic species, like F. frigidimaris, where this enzyme required a higher activation energy for catalysis $\left(27 \mathrm{~kJ} \mathrm{~mol}^{-1}\right)$ than PL002 at higher temperatures, while lower $\left(57 \mathrm{~kJ} \mathrm{~mol}^{-1}\right)$ at temperatures below $30^{\circ} \mathrm{C}$ [39]. This difference could be related to particular molecular adaptations in the psychrophilic F. frigidimaris as compared to the psychrotolerant Flavobacterium sp. PL002. 
A

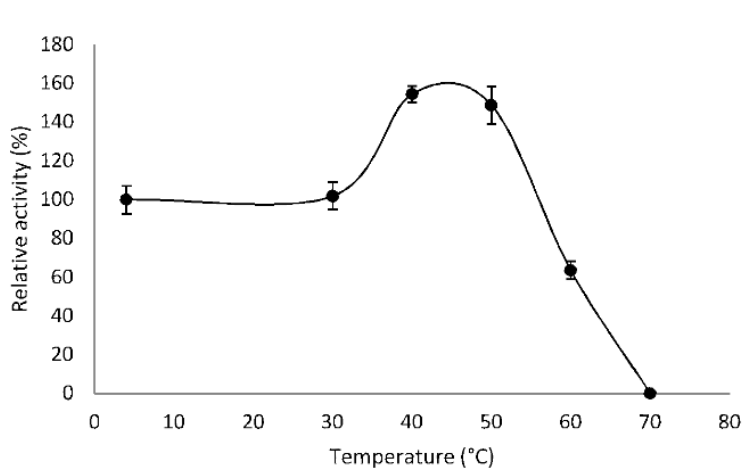

B

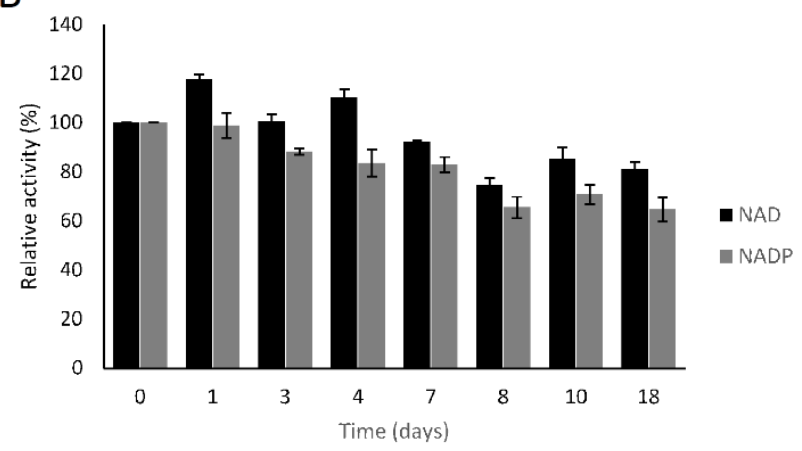

C

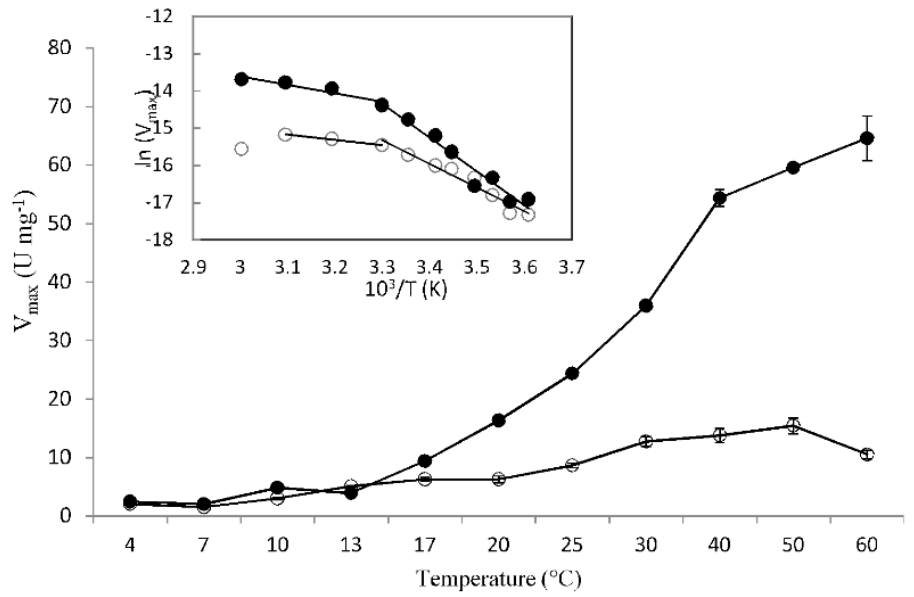

Figure 6. Temperature effect on the stability and activity of F-ALDH. (A) Thermal stability of the enzyme was determined after incubating the enzyme (200 $\mathrm{ng}$ ) for $10 \mathrm{~min}$ at various temperatures in the $4-70{ }^{\circ} \mathrm{C}$ interval, and further measuring the activity at $25^{\circ} \mathrm{C}$, in the presence of benzaldehyde and $\mathrm{NAD}^{+.}$(B) Long term stability of F-ALDH was evaluated after storing the purified enzyme at $4{ }^{\circ} \mathrm{C}$ for up to 18 days, and the activity when using $\mathrm{NAD}^{+}$(black) and $\mathrm{NADP}^{+}$(grey) as cofactors was measured at $25^{\circ} \mathrm{C}$. (C) The effect of temperature on the F-ALDH activity was determined by measuring the reaction at different temperatures. Isovaleraldehyde saturation curves were performed at various temperatures in the $4-60{ }^{\circ} \mathrm{C}$ interval in the presence of $\mathrm{NAD}^{+}(\bullet)$ and $\mathrm{NADP}^{+}(\mathrm{O})$, and the maximum velocity $\left(\mathrm{V}_{\max }\right)$ was calculated as described in Methods. The inset shows the corresponding Arrhenius plots.

\subsection{Kinetics of the Recombinant F-ALDH}

The F-ALDH steady state kinetic parameters (Table 3) were calculated for the aliphatic and aromatic substrates, isovaleraldehyde and benzaldehyde, respectively, when using both cofactors, $\mathrm{NAD}^{+}$and $\mathrm{NADP}^{+}$. The saturation curves for these substrates (Supplementary Figure S2) were hyperbolic, except for an inhibition effect at high concentrations of benzaldehyde in the NADP-dependent reaction (panel B) and of isovaleraldehyde in the presence of both cofactors (panels C and D). 
Table 3. Steady state kinetic parameters of F-ALDH.

\begin{tabular}{|c|c|c|c|c|c|c|}
\hline Variable Substrate & Second Substrate & $\begin{array}{c}\mathrm{K}_{\mathrm{M}} \\
(\mu \mathrm{M})\end{array}$ & 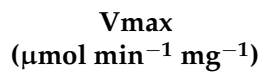 & $\begin{array}{l}\mathbf{k}_{\text {cat }} \\
\left(s^{-1}\right)\end{array}$ & $\underset{(\mathrm{mM})}{\mathrm{K}_{\mathrm{i}}}$ & $\begin{array}{c}k_{\mathrm{cat}} / \mathrm{K}_{\mathrm{M}} \\
\left(\mu \mathrm{M}^{-1} \mathrm{~s}^{-1}\right)\end{array}$ \\
\hline \multirow{2}{*}{ Isovaleraldehyde } & $\mathrm{NAD}^{+}$ & $197.0 \pm 39.1$ & $36.35 \pm 3.26$ & $100.04 \pm 8.98$ & $2.08 \pm 0.40$ & $0.50 \pm 0.22$ \\
\hline & $\mathrm{NADP}^{+}$ & $70.6 \pm 6.8$ & $12.40 \pm 0.39$ & $34.11 \pm 1.08$ & $2.96 \pm 0.28$ & $0.48 \pm 0.15$ \\
\hline \multirow{2}{*}{ Benzaldehyde } & $\mathrm{NAD}^{+}$ & $136.8 \pm 15.9$ & $12.63 \pm 0.40$ & $34.74 \pm 1.12$ & - & $0.25 \pm 0.07$ \\
\hline & $\mathrm{NADP}^{+}$ & $57.5 \pm 14.8$ & $2.90 \pm 0.20$ & $10.72 \pm 0.68$ & $15.33 \pm 5.7$ & $0.14 \pm 0.08$ \\
\hline \multirow{2}{*}{$\mathrm{NAD}^{+}$} & Isovaleraldehyde & $74.0 \pm 6.2$ & $21.32 \pm 0.32$ & $78.7 \pm 1.53$ & - & $1.06 \pm 0.24$ \\
\hline & Benzaldehyde & $32.5 \pm 3.2$ & $7.97 \pm 0.15$ & $29.24 \pm 0.54$ & - & $0.89+0.17$ \\
\hline \multirow[b]{2}{*}{$\mathrm{NADP}^{+}$} & Isovaleraldehyde & $1419.0 \pm 139.3$ & $19.13 \pm 0.75$ & $70.16 \pm 2.75$ & - & $0.05 \pm 0.02$ \\
\hline & Benzaldehyde & $430.8 \pm 105.0$ & $2.40 \pm 0.14$ & $8.96 \pm 0.54$ & - & $0.02+0.01$ \\
\hline
\end{tabular}

The catalytic activity measured at $30{ }^{\circ} \mathrm{C}$ varied with both the aldehyde substrate and the cofactor used in the reaction, exhibiting higher values for the NAD ${ }^{+}$-dependent reactions (Table 3). Overall, kcat appeared to be three-fold higher in the case of isovaleraldehyde $/ \mathrm{NAD}^{+}$than isovaleraldehyde/NADP ${ }^{+}$and benzaldehyde/NAD ${ }^{+}$, and 10 -fold higher than the benzaldehyde/ $\mathrm{NADP}^{+}$reaction rate. Nevertheless, the maximum initial rates for isovaleraldehyde/NADP ${ }^{+}$and benzaldehyde/NAD ${ }^{+}$are comparable. Meanwhile, the $K_{\mathrm{M}}$ for benzaldehyde and isovaleraldehyde ranged in the $136.8 \mu \mathrm{M}-197 \mu \mathrm{M}$ interval when using $\mathrm{NAD}^{+}$as a cofactor, and a 2.4- to 2.8-fold higher apparent affinity in the presence of NADP (Table 3). For the aliphatic isovaleraldehyde substrate, similar catalytic efficiencies $\left(k_{\text {cat }} / K_{\mathrm{M}}\right)$ were obtained independent of the cofactor, while it was double for benzaldehyde in the presence of $\mathrm{NAD}^{+}$. Moreover, this cold-adapted F-ALDH presented a two-fold higher catalytic efficiency when using the aliphatic substrate than the aromatic benzaldehyde (Table 3).

In comparison with other ALDHs (Supplementary Table S2), the $K_{\mathrm{M}}$ of F-ALDH for benzaldehyde/NAD ${ }^{+}$indicated a similar apparent affinity for this substrate as the homologous enzyme from Homo sapiens (saliva) [68] and Euglena gracilis (mitochondria) [69]. A higher apparent affinity for this aromatic substrate was observed relative to Nocardia sp. (by two-fold) [70] and H. sapiens ALDH7A1 (by four-fold) [71] homologous enzymes. Meanwhile, the Km of the cold-active F-ALDH is two-fold higher than for the Pseudomonas putida BADH [72], H. sapiens ALDH1B1 (liver) [73], and F. frigidimaris ALDH [39]. Among the ALDHs from cold environments, the closest relative F. frigidimaris ALDH (89\% identity) appeared to have a higher apparent affinity for this substrate than PL002 that could be associated with a different molecular adaptation to cold environments, defining it as a psychrophilic bacterium [39]. Interestingly, ALDH2 from human liver mitochondria has an apparent affinity approximately 8000 times higher than F-ALDH, suggesting a different metabolic role involving this substrate in the two organisms [74]. For the same substrate and cofactor, the turnover number of F-ALDH was eight-fold higher than that of ALDH2 from the mitochondrial liver of H. sapiens, and just three times lower than P. putida ALDH, while the corresponding catalytic efficiency wase only six-fold higher for P. putida and 1000-fold higher for $H$. sapiens ALDH2 from liver mitochondria [72,74], respectively.

In the case of the benzaldehyde $/ \mathrm{NADP}^{+}$reaction, the apparent affinity of F-ALDH was comparable with that of the homologous enzyme from P. putida [72], was higher than the $R$. norvegicus mitochondrial ALDH1 from the liver [75] by 30-fold, and was higher than ALDHs from E. coli [27] and R. norvegicus (liver/microsome) [75] by 100-fold. Meanwhile, the turnover number was comparable with that of ALDH2 from E. coli, and four-fold lower than P. putida ALDH, resulting in a 60-fold higher catalytic efficiency as compared to E. coli ALDH [27], and five-fold lower than that of the P. putida enzyme [72]. A comparable $\mathrm{Km}$ value was also observed for the isovaleraldehyde/ $\mathrm{NAD}^{+}$reaction of Flavobacterium PL002 and Klebsiella pneumoniae ALDH [19], while the apparent affinity for this substrate was three-fold lower than that of the E. coli enzyme [27]. However, considering that the turnover number of F-ALDH was greater (by five-fold) than in the case of $E$. coli and the K. pneumoniae homologs, the calculated catalytic efficiency of this cold-active enzyme is 
significantly higher, by six and seventeen times as compared to that of the two bacterial dehydrogenases, respectively $[19,27]$.

Unlike other ALDHs (Supplementary Table S2), the extremozyme, F-ALDH, showed substrate inhibition by isovaleraldehyde at high concentrations $(>2 \mathrm{mM})$ that was not observed for ALDHs from K. pneumoniae [19] and E. coli K-12 [27] when using the same substrate. Meanwhile, several aldehydes were reported to have an inhibitory effect, such as betaine aldehyde $\left(K_{\mathrm{i}}=0.34 \mathrm{mM}\right)$ for the $S$. aureus ALDH [62], acetaldehyde for the Saccharomyces cerevisiae $\left(K_{\mathrm{i}}=2.55 \mathrm{mM}\right)$ [76] and Nocardia sp. $\left(K_{\mathrm{i}}=5 \mathrm{mM}\right)$ [70] ALDHs, formaldehyde $\left(K_{\mathrm{i}}=6 \mathrm{mM}\right)$ and benzaldehyde $\left(K_{\mathrm{i}}=2 \mathrm{mM}\right)$ for the Nocardia sp. ALDH [70], whereas there was a lower response for butyraldehyde for the Lachnoclostridium phytofermentans dehydrogenase $\left(K_{\mathrm{i}}=144.3 \mathrm{mM}\right)$ [77] and isobutanal for Rattus norvegicus ALDH $\left(K_{\mathrm{i}}=100.1 \mathrm{mM}\right)$ [78]. Interestingly, in the case of F-ALDH, the NAD ${ }^{+}$-dependent oxidation of benzaldehyde was not inhibited by the substrate excess, unlike the NADP ${ }^{+}$-dependent reaction that was inhibited by concentrations of this substrate above $15 \mathrm{mM}$.

Furthermore, based on the good affinity of this cold-active ALDH for benzaldehyde, an electrochemical assay using the enzyme in solution and a stable biosensor for benzaldehyde using immobilized F-ALDH were developed [79]. The biosensor was suitable for the determination of benzaldehyde impurities in benzyl alcohol, a non-active ingredient in liquid drugs. The biosensor provides a simpler, more economical alternative to the corresponding standard chromatographic tests for the quality control of benzyl alcohol. In addition, a patent application was reported for an electrochemical assay for the detection of thiram exploiting the inhibitory action of this fungicide on F-ALDH [80]. Thus, the high apparent affinity for aldehyde substrates like benzaldehyde and the high stability are also important assets for using this Antarctic bacterial enzyme in biosensors for practical applications [81].

It is well known that immobilization improves the enzyme stability under harsh conditions, enabling its repeated use for cost-effective industrial applications [82,83]. While immobilization could lead to a certain loss in enzymatic activity and to changes in the substrate specificity or substrate inhibition, the advantages of immobilization for bioreactors for many industrial applications or for the development of analytical devices, such as biosensors, are undeniable. For example, immobilization of F-ALDH by cross-linking with glutaraldehyde in a matrix of bovine serum albumin (a largely used method in the biosensing field) led to a change in $\mathrm{Km}$ from $145 \mu \mathrm{mol} / \mathrm{L}$ to $386 \mu \mathrm{mol} / \mathrm{L}$ [79]. Nonetheless, the immobilization enabled repeatable measurements in a flow injection system for over three days of extensive use at 60 tests/day [79]. Other methods enabling controlled quantitative enzyme immobilization, such as exploiting the nickel-histidine affinity in the case of His-tagged enzymes [84], immobilization on nanomaterials with high loading capacities [85], enzyme nanoflowers [86], CLEAs, or other recent strategies [83] could lead to better performance of immobilized F-ALDH.

Regarding industrial applications, the recycling of the soluble cofactor $\mathrm{NAD}^{+}$is one of the important aspects to consider [87]. For cost-effective processes, this is typically achieved by coupled enzymatic reactions. In this respect, the high apparent affinity for $\mathrm{NAD}^{+}$(Km ranging from 32.5 to $74 \mu \mathrm{M}$ depending on the aldehyde substrate used), the ability to catalyze aldehydes oxidation at low temperatures with a high catalytic efficiency $\left(0.89-1.06 \mu \mathrm{M}^{-1} \mathrm{~s}^{-1}\right)$, and the important stability determined over a broad range of temperatures of up to $50{ }^{\circ} \mathrm{C}$ of the recombinant Antarctic F-ALDH constitute valuable characteristics of a promising catalyst for cofactor regeneration by enzymatic processes at industrial scale [87].

\section{Conclusions}

In search of cold-active aldehyde dehydrogenases as potent and stable extremozymes for catalyzing applicative aldehyde conversion reactions at low temperatures, a novel ALDH was isolated from an Antarctic psychrotrophic bacterium and characterized. The high heterologous expression yield of this recombinant enzyme and the one-step purifi- 
cation were useful prerequisites for putative-enhanced catalysts. The synopsis of the structural and functional properties highlighted a NAD $(\mathrm{P})^{+}$-dependent dehydrogenase with a preference towards the $\mathrm{NAD}^{+}$cofactor catalyzing a broad range of aliphatic and aromatic aldehyde oxidation is of interest in biotechnologies and biosensing. In addition, a particularly high thermal stability at temperatures up to $55^{\circ} \mathrm{C}$, rather common for (hyper)thermophiles-originating enzymes, together with activity preservation in the presence of various ions and compounds, constitute clear advantages for developing such an extremozyme-based biocatalyst. Moreover, the ability to carry out low-temperature catalysis characterized by high apparent affinity for benzaldehyde and isovaleraldehyde added to the benefit of using this cold-active F-ALDH in industrial processes with energy savings. Hence, these characteristics of the novel ALDH from the Antarctic Flavobacterium PL002 strain constitute promising leads for using F-ALDH as a stable catalyst in monitoring processes at low temperatures. Alternatively, this cold-active enzyme already demonstrated its potential for biosensor development exploiting both the direct affinity for aldehyde substrates and the inhibition by dithiocarbamate fungicides.

Supplementary Materials: The following are available online at https:/ /www.mdpi.com/article/10 .3390 / fermentation8010007/s1, Figure S1: Thermal stability of F-ALDH at $50{ }^{\circ} \mathrm{C}$, Figure S2: Substrate saturation curves of F-ALDH, Table S1: Catalytic parameters of ALDHs

Author Contributions: C.P. performed the experimental design and data interpretation, coordinated the project and wrote the manuscript with major input from G.N.-P.; P.L. isolated the bacterial strain and performed the phylogenetic analysis; G.N.-P. carried out the structural and functional characterization of the enzyme and sequence analyses; G.N.-P., G.R.G., and V.I.P. performed the gene expression and enzyme purification and produced protein batches for functional analyses; A.V. contributed to the experimental design and biochemical investigations. All authors have read and agreed to the published version of the manuscript.

Funding: This work was financially supported by the UEFISCDI projects PN-III-P2-2.1-PED-20160116 and ERANET-M-ENZ4IFACES ctr. 166/2020.

Institutional Review Board Statement: Not applicable.

Informed Consent Statement: Not applicable.

Data Availability Statement: All data supporting the conclusions of this article are included in the manuscript.

Conflicts of Interest: The authors declare no conflict of interest.

\section{References}

1. Seckbach, J.O.A.S.-L.H. Polyextremophiles: Life under Multiple Forms of Stress; Springer: Dordrecht, The Netherlands, 2013.

2. Merino, N.; Aronson, H.S.; Bojanova, D.P.; Feyhl-Buska, J.; Wong, M.L.; Zhang, S.; Giovannelli, D. Living at the Extremes: Extremophiles and the Limits of Life in a Planetary Context. Front. Microbiol. 2019, 10, 780. [CrossRef] [PubMed]

3. Vila, E.; Hornero-Méndez, D.; Azziz, G.; Lareo, C.; Saravia, V. Carotenoids from heterotrophic bacteria isolated from Fildes Peninsula, King George Island, Antarctica. Biotechnol. Rep. 2019, 21, e00306. [CrossRef] [PubMed]

4. Paris, L.; Atala, C.; Gallardo-Cerda, J.; Gonzalez-Aravena, M.; Rodrigo De La, I.; Rómulo, O.; Torres-Díaz, C.; Trefault, N.; Molina-Montenegro, M.A.; IV, H.D.L. Isolation and characterization of an Antarctic Flavobacterium strain with agarase and alginate lyase activities. Pol. Polar Res. 2016, 37, 403-419.

5. Williams, T.J.; Wilkins, D.; Long, E.; Evans, F.; DeMaere, M.Z.; Raftery, M.J.; Cavicchioli, R. The role of planktonic Flavobacteria in processing algal organic matter in coastal East Antarctica revealed using metagenomics and metaproteomics. Environ. Microbiol. 2013, 15, 1302-1317. [CrossRef] [PubMed]

6. Kumar, P.; Sharma, S. Enzymes in green chemistry: The need for environment and sustainability. Int. J. Appl. Res. 2016, 2, 337-341.

7. Xu, F. Applications of oxidoreductases: Recent progress. Ind. Biotechnol. 2005, 1, 38-50. [CrossRef]

8. Singh, R.; Kumar, M.; Mittal, A.; Mehta, P.K. Microbial enzymes: Industrial progress in 21st century. 3 Biotech 2016, 6, 174. [CrossRef]

9. Siddiqui, K.S.; Cavicchioli, R. Cold-adapted enzymes. Annu. Rev. Biochem. 2006, 75, 403-433. [CrossRef]

10. Struvay, C.; Feller, G. Optimization to low temperature activity in psychrophilic enzymes. Int. J. Mol. Sci. 2012, 13, 11643-11665. [CrossRef] 
11. Georlette, D.; Blaise, V.; Collins, T.; D'Amico, S.; Gratia, E.; Hoyoux, A.; Marx, J.C.; Sonan, G.; Feller, G.; Gerday, C. Some like it cold: Biocatalysis at low temperatures. FEMS Microbiol. Rev. 2004, 28, 25-42. [CrossRef]

12. Morita, R.Y. Psychrophilic bacteria. Bacteriol. Rev. 1975, 39, 144-167. [CrossRef] [PubMed]

13. Laybourn-Parry, J.; Pearce, D.A. The biodiversity and ecology of Antarctic lakes: Models for evolution. Philos. Trans. R. Soc. Lond. B Biol. Sci. 2007, 362, 2273-2289. [CrossRef] [PubMed]

14. Di Donato, P.; Buono, A.; Poli, A.; Finore, I.; Abbamondi, G.R.; Nicolaus, B.; Lama, L. Exploring Marine Environments for the Identification of Extremophiles and Their Enzymes for Sustainable and Green Bioprocesses. Sustainability 2019, 11, 149. [CrossRef]

15. Danilovich, M.; Sánchez, L.; Acosta, F.; Delgado, O. Antarctic bioprospecting: In pursuit of microorganisms producing new antimicrobials and enzymes. Polar Biol. 2018, 41, 1417-1433. [CrossRef]

16. Santiago, M.; Ramírez-Sarmiento, C.A.; Zamora, R.A.; Parra, L.P. Discovery, Molecular Mechanisms, and Industrial Applications of Cold-Active Enzymes. Front. Microbiol. 2016, 7, 1408. [CrossRef]

17. Barnes, D.K.A.; Clarke, A. Antarctic marine biology. Curr. Biol. 2011, 21, R451-R457. [CrossRef]

18. Lavin, P.; Henríquez-Castillo, C.; Yong, S.T.; Valenzuela-Heredia, D.; Oses, R.; Frez, K.; Borba, M.P.; Purcarea, C.; Wong, C. Draft Genome Sequence of Antarctic Psychrotroph Streptomyces fildesensis Strain INACH3013, Isolated from King George Island Soil. Microbiol. Resour. Announc. 2021, 10, e01453-20. [CrossRef]

19. Muthusamy, C.; Sukumaran, R. Marine Microbial Enzymes. Biotechnology 2010, 9, 47-79.

20. Bakunina, I.; Nedashkovskaya, O.; Kim, S.; Zvyagintseva, T.; Mikhailov, V. Diversity of glycosidase activities in the bacteria of the phylum Bacteroidetes isolated from marine algae. Microbiology 2012, 81. [CrossRef]

21. Tropeano, M.; Coria, S.; Turjanski, A.; Cicero, D.; Bercovich, A.; Mac Cormack, W.; Vázquez, S. Culturable heterotrophic bacteria from Potter Cove, Antarctica, and their hydrolytic enzymes production. Polar Res. 2012, 31, 18507. [CrossRef]

22. Nb, C.; Ruiz-Toquica, J.; Lopez-Kleine, L.; Montoya-Castano, D. Epiphytic Bacteria of Macroalgae of the Genus Ulva and Their Potential in Producing Enzymes Having Biotechnological Interest. J. Mar. Biol. Oceanogr. 2016, 5, 2-9. [CrossRef]

23. Xie, M.; Li, J.; He, P.; Lin, X. Expression and characterization of a bifunctional alginate lyase named Al163 from the Antarctic bacterium Pseudoalteromonas sp. NJ-21. J. Oceanol. Limnol. 2018, 36, 1304-1314. [CrossRef]

24. Marchitti, S.A.; Brocker, C.; Stagos, D.; Vasiliou, V. Non-P450 aldehyde oxidizing enzymes: The aldehyde dehydrogenase superfamily. Expert Opin. Drug Metab. Toxicol. 2008, 4, 697-720. [CrossRef] [PubMed]

25. Bains, J.; Boulanger, M.J. Structural and biochemical characterization of a novel aldehyde dehydrogenase encoded by the benzoate oxidation pathway in Burkholderia xenovorans LB400. J. Mol. Biol. 2008, 379, 597-608. [CrossRef] [PubMed]

26. Borisova, S.A.; Christman, H.D.; Metcalf, M.E.; Zulkepli, N.A.; Zhang, J.K.; van der Donk, W.A.; Metcalf, W.W. Genetic and biochemical characterization of a pathway for the degradation of 2-aminoethylphosphonate in Sinorhizobium meliloti 1021. $J$. Biol. Chem. 2011, 286, 22283-22290. [CrossRef]

27. Jo, J.E.; Mohan Raj, S.; Rathnasingh, C.; Selvakumar, E.; Jung, W.C.; Park, S. Cloning, expression, and characterization of an aldehyde dehydrogenase from Escherichia coli K-12 that utilizes 3-Hydroxypropionaldehyde as a substrate. Appl. Microbiol. Biotechnol. 2008, 81, 51-60. [CrossRef]

28. Zhou, S.; Catherine, C.; Rathnasingh, C.; Somasundar, A.; Park, S. Production of 3-hydroxypropionic acid from glycerol by recombinant Pseudomonas denitrificans. Biotechnol. Bioeng. 2013, 110, 3177-3187. [CrossRef]

29. Ohta, T.; Tani, A.; Kimbara, K.; Kawai, F. A novel nicotinoprotein aldehyde dehydrogenase involved in polyethylene glycol degradation. Appl. Microbiol. Biotechnol. 2005, 68, 639-646. [CrossRef]

30. Okibe, N.; Amada, K.; Hirano, S.; Haruki, M.; Imanaka, T.; Morikawa, M.; Kanaya, S. Gene cloning and characterization of aldehyde dehydrogenase from a petroleum-degrading bacterium, strain HD-1. J. Biosci. Bioeng. 1999, 88, 7-11. [CrossRef]

31. Li, X.; Li, Y.; Wei, D.; Li, P.; Wang, L.; Feng, L. Characterization of a broad-range aldehyde dehydrogenase involved in alkane degradation in Geobacillus thermodenitrificans NG80-2. Microbiol. Res. 2010, 165, 706-712. [CrossRef]

32. Kato, T.; Miyanaga, A.; Kanaya, S.; Morikawa, M. Gene cloning and characterization of an aldehyde dehydrogenase from long-chain alkane-degrading Geobacillus thermoleovorans B23. Extremophiles 2010, 14, 33-39. [CrossRef]

33. Avramescu, A.; Andreescu, S.; Noguer, T.; Bala, C.; Andreescu, D.; Marty, J.L. Biosensors designed for environmental and food quality control based on screen-printed graphite electrodes with different configurations. Anal. Bioanal. Chem. 2002, 374, 25-32. [CrossRef]

34. Badalyan, A.; Dierich, M.; Stiba, K.; Schwuchow, V.; Leimkühler, S.; Wollenberger, U. Electrical Wiring of the Aldehyde Oxidoreductase PaoABC with a Polymer Containing Osmium Redox Centers: Biosensors for Benzaldehyde and GABA. Biosensors 2014, 4, 403-421. [CrossRef] [PubMed]

35. Badalyan, A.; Neumann-Schaal, M.; Leimkühler, S.; Wollenberger, U. A Biosensor for Aromatic Aldehydes Comprising the Mediator Dependent PaoABC-Aldehyde Oxidoreductase. Electroanalysis 2013, 25, 101-108. [CrossRef]

36. Ghica, M.E.; Pauliukaite, R.; Marchand, N.; Devic, E.; Brett, C.M. An improved biosensor for acetaldehyde determination using a bienzymatic strategy at poly(neutral red) modified carbon film electrodes. Anal. Chim. Acta. 2007, 591, 80-86. [CrossRef] [PubMed]

37. Iitani, K.; Chien, P.-J.; Suzuki, T.; Toma, K.; Arakawa, T.; Iwasaki, Y.; Mitsubayashi, K. Improved Sensitivity of Acetaldehyde Biosensor by Detecting ADH Reverse Reaction-Mediated NADH Fluoro-Quenching for Wine Evaluation. ACS Sens. 2017, 2, 940-946. [CrossRef] 
38. Pariente, F.; Lorenzo, E.; Tobalina, F.; Abruna, H.D. Aldehyde Biosensor Based on the Determination of NADH Enzymically Generated by Aldehyde Dehydrogenase. Anal. Chem. 1995, 67, 3936-3944. [CrossRef]

39. Yamanaka, Y.; Kazuoka, T.; Yoshida, M.; Yamanaka, K.; Oikawa, T.; Soda, K. Thermostable aldehyde dehydrogenase from psychrophile, Cytophaga sp. KUC-1: Enzymological characteristics and functional properties. Biochem. Bioph. Res. Commun. 2002, 298, 632-637. [CrossRef]

40. Teoh, C.P.; Lavin, P.; Najimudin, N.; Lee, P.C.; Iancu, L.; Purcarea, C.; Wong, C. Draft Genome Sequence of Flavobacterium sp. Strain PL002, Isolated from Antarctic Porphyra Algae. Microbiol. Resour. Announc. 2021, 10, e00063-21. [CrossRef]

41. Reasoner, D.J.; Geldreich, E.E. A new medium for the enumeration and subculture of bacteria from potable water. Appl. Environ. Microbiol. 1985, 49, 1-7. [CrossRef]

42. Purcarea, C.; Ahuja, A.; Lu, T.; Kovari, L.; Guy, H.I.; Evans, D.R. Aquifex aeolicus aspartate transcarbamoylase, an enzyme specialized for the efficient utilization of unstable carbamoyl phosphate at elevated temperature. J. Biol. Chem. 2003, 278, 52924-52934. [CrossRef] [PubMed]

43. Laemmli, U.K. Cleavage of Structural Proteins during the Assembly of the Head of Bacteriophage T4. Nature 1970, 227, 680-685. [CrossRef] [PubMed]

44. Gasteiger, E.; Gattiker, A.; Hoogland, C.; Ivanyi, I.; Appel, R.D.; Bairoch, A. ExPASy: The proteomics server for in-depth protein knowledge and analysis. Nucleic Acids Res. 2003, 31, 3784-3788. [CrossRef] [PubMed]

45. Madeira, F.; Park, Y.M.; Lee, J.; Buso, N.; Gur, T.; Madhusoodanan, N.; Basutkar, P.; Tivey, A.R.N.; Potter, S.C.; Finn, R.D.; et al. The EMBL-EBI search and sequence analysis tools APIs in 2019. Nucleic Acids Res. 2019, 47, W636-W641. [CrossRef]

46. Chen, C.; Joo, J.C.; Brown, G.; Stolnikova, E.; Halavaty, A.S.; Savchenko, A.; Anderson, W.F.; Yakunin, A.F. Structure-based mutational studies of substrate inhibition of betaine aldehyde dehydrogenase BetB from Staphylococcus aureus. Appl. Environ. Microbiol. 2014, 80, 3992-4002. [CrossRef]

47. Le, S.Q.; Gascuel, O. An Improved General Amino Acid Replacement Matrix. Mol. Biol. Evol. 2008, 25, 1307-1320. [CrossRef]

48. Jones, D.T.; Taylor, W.R.; Thornton, J.M. The rapid generation of mutation data matrices from protein sequences. Comput. Appl. Biosci. 1992, 8, 275-282. [CrossRef]

49. Van Trappen, S.; Vandecandelaere, I.; Mergaert, J.; Swings, J. Flavobacterium degerlachei sp. nov., Flavobacterium frigoris sp. nov. and Flavobacterium micromati sp. nov., novel psychrophilic bacteria isolated from microbial mats in Antarctic lakes. Int. J. Syst. Evol. Microbiol. 2004, 54, 85-92. [CrossRef]

50. Aslam, Z.; Im, W.T.; Kim, M.K.; Lee, S.T. Flavobacterium granuli sp. nov., isolated from granules used in a wastewater treatment plant. Int. J. Syst. Evol. Microbiol. 2005, 55, 747-751. [CrossRef]

51. McCammon, S.A.; Bowman, J.P. Taxonomy of Antarctic Flavobacterium species: Description of Flavobacterium gillisiae sp. nov., Flavobacterium tegetincola sp. nov., and Flavobacterium xanthum sp. nov., nom. rev. and reclassification of [Flavobacterium] salegens as Salegentibacter salegens gen. nov., comb. nov. Int. J. Syst. Evol. Microbiol. 2000, 50 Pt 3, 1055-1063. [CrossRef]

52. Lee, Y.; Jeon, C.O. Flavobacterium alvei sp. nov., isolated from a freshwater river. Int. J. Syst. Evol. Microbiol. 2018, 68, 1919-1924. [CrossRef]

53. Dong, K.; Liu, H.; Zhang, J.; Zhou, Y.; Xin, Y. Flavobacterium xueshanense sp. nov. and Flavobacterium urumqiense sp. nov., two psychrophilic bacteria isolated from glacier ice. Int. J. Syst. Evol. Microbiol. 2012, 62, 1151-1157. [CrossRef] [PubMed]

54. Heim, R.; Strehler, E.E. Cloning an Escherichia coli gene encoding a protein remarkably similar to mammalian aldehyde dehydrogenases. Gene 1991, 99, 15-23. [CrossRef]

55. Hayes, K.; Noor, M.R.; Djeghader, A.; Armshaw, P.; Pembroke, T.; Tofail, S.A.M.; Soulimane, T. The quaternary structure of Thermus thermophilus aldehyde dehydrogenase is stabilized by an evolutionary distinct C-terminal arm extension. Sci. Rep. 2018, 8, 1-14. [CrossRef] [PubMed]

56. Liu, T.; Hao, L.; Wang, R.; Liu, B. Molecular characterization of a thermostable aldehyde dehydrogenase (ALDH) from the hyperthermophilic archaeon Sulfolobus tokodaii strain 7. Extremophiles 2013, 17, 181-190. [CrossRef]

57. d Amico, S.; Collins, T.; Marx, J.C.; Feller, G.; Gerday, C.; Gerday, C. Psychrophilic microorganisms: Challenges for life. EMBO Rep. 2006, 7, 385-389. [CrossRef]

58. Hempel, J.; Lindahl, R.; Perozich, J.; Wang, B.; Kuo, I.; Nicholas, H. Beyond the catalytic core of ALDH: A web of important residues begins to emerge. Chem. Biol. Interact. 2001, 130-132, 39-46. [CrossRef]

59. Moore, S.A.; Baker, H.M.; Blythe, T.J.; Kitson, K.E.; Kitson, T.M.; Baker, E.N. Sheep liver cytosolic aldehyde dehydrogenase: The structure reveals the basis for the retinal specificity of class 1 aldehyde dehydrogenases. Structure 1998, 6, 1541-1551. [CrossRef]

60. Perozich, J.; Nicholas, H.; Wang, B.C.; Lindahl, R.; Hempel, J. Relationships within the aldehyde dehydrogenase extended family. Protein Sci. 1999, 8, 137-146. [CrossRef]

61. Muñoz-Clares, R.A.; Díaz-Sánchez, A.G.; González-Segura, L.; Montiel, C. Kinetic and structural features of betaine aldehyde dehydrogenases: Mechanistic and regulatory implications. Arch. Biochem. Biophys. 2010, 493, 71-81. [CrossRef]

62. Halavaty, A.S.; Rich, R.L.; Chen, C.; Joo, J.C.; Minasov, G.; Dubrovska, I.; Winsor, J.R.; Myszka, D.G.; Duban, M.; Shuvalova, L.; et al. Structural and functional analysis of betaine aldehyde dehydrogenase from Staphylococcus aureus. Acta Crystallogr. D Biol. Crystallogr. 2015, 71, 1159-1175. [CrossRef] [PubMed]

63. Lindahl, R. Aldehyde dehydrogenases and their role in carcinogenesis. Crit. Rev. Biochem. Mol. Biol. 1992, 27, 283-335. [CrossRef]

64. Shortall, K.; Djeghader, A.; Magner, E.; Soulimane, T. Insights into Aldehyde Dehydrogenase Enzymes: A Structural Perspective. Front. Mol. Biosci. 2021, 8, 410. [CrossRef] [PubMed] 
65. Smit, B.; Engels, W.; Smit, G. Branched chain aldehydes: Production and breakdown pathways and relevance for flavour in foods. Appl. Microbiol. Biotechnol. 2008, 81, 987-999. [CrossRef] [PubMed]

66. Cuesta, A.; Taunton, J. Lysine-Targeted Inhibitors and Chemoproteomic Probes. Annu. Rev. Biochem. 2019, 88, 365-381. [CrossRef]

67. Reichardt, P.; Schreiber, A.; Wichmann, G.; Metzner, G.; Efer, J.; Raabe, F. Identification and quantification of in vitro adduct formation between protein reactive xenobiotics and a lysine-containing model peptide. Environ. Toxicol. 2003, 18, 29-36. [CrossRef]

68. Giebułtowicz, J.; Wolinowska, R.; Sztybor, A.; Pietrzak, M.; Wroczyński, P.; Wierzchowski, J. Salivary aldehyde dehydrogenase: Activity towards aromatic aldehydes and comparison with recombinant ALDH3A1. Molecules 2009, 14, 2363-2372. [CrossRef]

69. Rodríguez-Zavala, J.S.; Allali-Hassani, A.; Weiner, H. Characterization of E. coli tetrameric aldehyde dehydrogenases with atypical properties compared to other aldehyde dehydrogenases. Protein Sci. 2006, 15, 1387-1396. [CrossRef]

70. Van Ophem, P.W.; Duine, J.A. Different types of formaldehyde-oxidizing dehydrogenases in Nocardia species 239: Purification and characterization of an NAD-dependent aldehyde dehydrogenase. Arch. Biochem. Biophys. 1990, 282, 248-253. [CrossRef]

71. Brocker, C.; Lassen, N.; Estey, T.; Pappa, A.; Cantore, M.; Orlova, V.V.; Chavakis, T.; Kavanagh, K.L.; Oppermann, U.; Vasiliou, V. Aldehyde dehydrogenase 7A1 (ALDH7A1) is a novel enzyme involved in cellular defense against hyperosmotic stress. J. Biol. Chem. 2010, 285, 18452-18463. [CrossRef]

72. McLeish, M.J.; Kneen, M.M.; Gopalakrishna, K.N.; Koo, C.W.; Babbitt, P.C.; Gerlt, J.A.; Kenyon, G.L. Identification and Characterization of a Mandelamide Hydrolase and an NAD $(\mathrm{P})^{+}$-Dependent Benzaldehyde Dehydrogenase from Pseudomonas putida ATCC 12633. J. Bacteriol. 2003, 185, 2451-2456. [CrossRef] [PubMed]

73. Stagos, D.; Chen, Y.; Brocker, C.; Donald, E.; Jackson, B.C.; Orlicky, D.J.; Thompson, D.C.; Vasiliou, V. Aldehyde dehydrogenase 1B1: Molecular cloning and characterization of a novel mitochondrial acetaldehyde-metabolizing enzyme. Drug Metab. Dispos. 2010, 38, 1679-1687. [CrossRef] [PubMed]

74. Klyosov, A.A. Kinetics and Specificity of Human Liver Aldehyde Dehydrogenases toward Aliphatic, Aromatic, and Fused Polycyclic Aldehydes. Biochemistry 1996, 35, 4457-4467. [CrossRef]

75. Lindahl, R.; Evces, S. Rat liver aldehyde dehydrogenase. I. Isolation and characterization of four high Km normal liver isozymes. J. Biol. Chem. 1984, 259, 11986-11990. [CrossRef]

76. Eggert, M.W.; Byrne, M.E.; Chambers, R.P. Kinetic involvement of acetaldehyde substrate inhibition on the rate equation of yeast aldehyde dehydrogenase. Appl. Biochem. Biotechnol. 2012, 168, 824-833. [CrossRef] [PubMed]

77. Tuck, L.R.; Altenbach, K.; Ang, T.F.; Crawshaw, A.D.; Campopiano, D.J.; Clarke, D.J.; Marles-Wright, J. Insight into Coenzyme A cofactor binding and the mechanism of acyl-transfer in an acylating aldehyde dehydrogenase from Clostridium phytofermentans. Sci. Rep. 2016, 6, 22108. [CrossRef] [PubMed]

78. Bedino, S.; Testore, G.; Obert, F. Initial characterization of aldehyde dehydrogenase from rat testis cytosol. Biol. Chem. Hoppe Seyler 1990, 371, 95-101. [CrossRef]

79. Titoiu, A.M.; Necula-Petrareanu, G.; Visinescu, D.; Dinca, V.; Bonciu, A.; Mihailescu, C.N.; Purcarea, C.; Boukherroub, R.; Szunerits, S.; Vasilescu, A. Flow injection enzymatic biosensor for aldehydes based on a Meldola Blue-Ni complex electrochemical mediator. Microchim. Acta 2020, 187, 550. [CrossRef]

80. Bucur, B.; Munteanu, F.; Marty, J.-L.; Vasilescu, A. Advances in Enzyme-Based Biosensors for Pesticide Detection. Biosensors 2018, 8, 27. [CrossRef]

81. Fanjul-Bolado, P.; Fogel, R.; Limson, J.; Purcarea, C.; Vasilescu, A. Advances in the Detection of Dithiocarbamate Fungicides: Opportunities for Biosensors. Biosensors 2021, 11, 12. [CrossRef]

82. Sheldon, R.A.; van Pelt, S. Enzyme immobilisation in biocatalysis: Why, what and how. Chem. Soc. Rev. 2013, 42, 6223-6235. [CrossRef] [PubMed]

83. Sheldon, R.A.; Basso, A.; Brady, D. New frontiers in enzyme immobilisation: Robust biocatalysts for a circular bio-based economy. Chem. Soc. Rev. 2021, 50, 5850-5862. [CrossRef] [PubMed]

84. Zhou, L.-J.; Li, R.-F.; Li, X.-Y.; Zhang, Y.-W. One-step selective affinity purification and immobilization of His-tagged enzyme by recyclable magnetic nanoparticles. Eng. Life Sci. 2021, 21, 364-373. [CrossRef] [PubMed]

85. An, J.; Li, G.; Zhang, Y.; Zhang, T.; Liu, X.; Gao, F.; Peng, M.; He, Y.; Fan, H. Recent Advances in Enzyme-Nanostructure Biocatalysts with Enhanced Activity. Catalysts 2020, 10, 338. [CrossRef]

86. Zhang, M.; Zhang, Y.; Yang, C.; Ma, C.; Tang, J. Enzyme-inorganic hybrid nanoflowers: Classification, synthesis, functionalization and potential applications. Chem. Eng. J. 2021, 415, 129075. [CrossRef]

87. Wang, X.; Saba, T.; Yiu, H.H.P.; Howe, R.F.; Anderson, J.A.; Jiafu, S. Cofactor NAD(P)H Regeneration Inspired by Heterogeneous Pathways. Chem 2017, 2, 621-654. [CrossRef] 